Supporting Information

\title{
Living Aqueous Polymerization of Ethylene in Microemulsion with Ro-bust Ni(II) Phosphinophenolato Catalysts
}

\author{
Fei Lin, Tobias O. Morgen, and Stefan Mecking* \\ Chair of Chemical Materials Science, Department of Chemistry, University of Konstanz, \\ Universitätsstrasse 10, 78457 Konstanz, Germany
}




\section{Table of Contents}

1 General methods and materials .................................................................................... 3

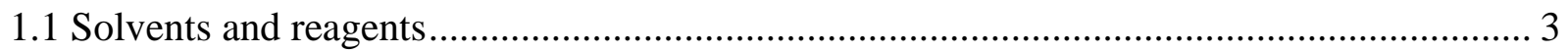

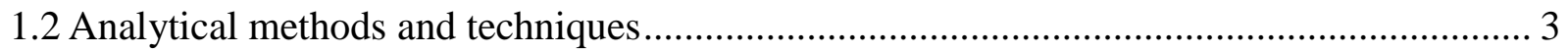

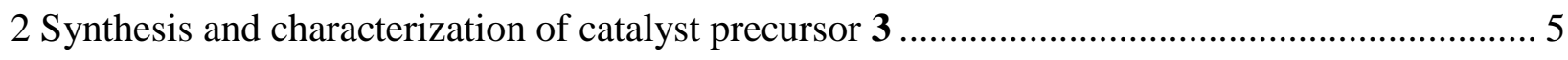

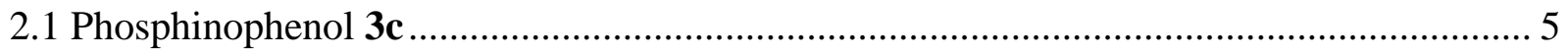

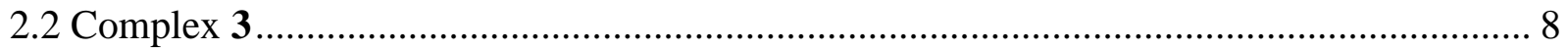

3 Exposure of catalyst precursors to 1 -hexanol .................................................................. 12

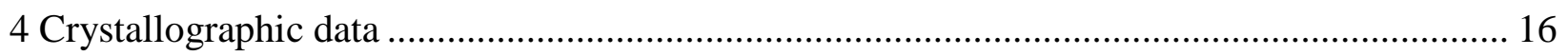

5 Ethylene polymerization procedure and polymer analysis ............................................. 17

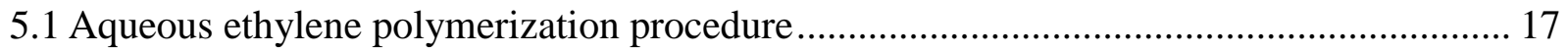

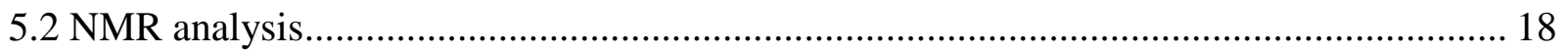

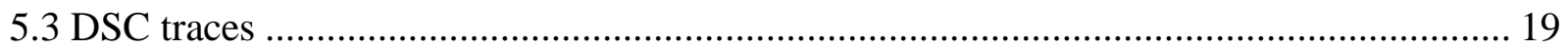

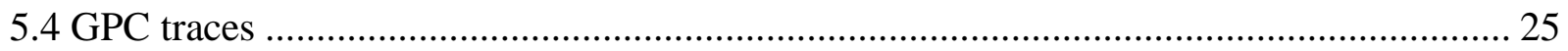

5.5 Mass flow profiles of aqueous polymerizations ...................................................... 26

6 Particle analysis of polyethylene nanoparticle dispersions............................................... 28

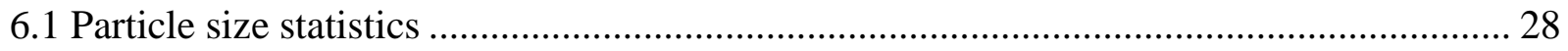

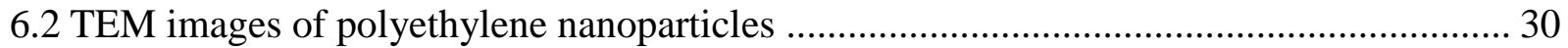

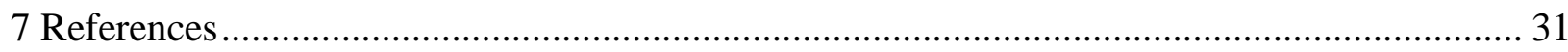




\section{General methods and materials}

Unless noted otherwise, all manipulations of air and moisture sensitive materials were carried out under inert gas atmosphere using standard glovebox and Schlenk techniques.

\subsection{Solvents and reagents}

Solvents were dried and degassed using standard laboratory techniques. Oxygen was removed from ethyl acetate and DMF by freeze-pump-thaw degassing and storage over molecular sieves prior to use. Pentane and diethyl ether were dried and freed from oxygen with a MB-SPS-800 solvent purification system by MBRAUN and molecular sieves. Water was deoxygenated by distillation under a constant nitrogen stream. Benzene was distilled from sodium. $n$-Butyllithium ( $n$-BuLi; $2.5 \mathrm{M}$ solution in $n$-hexane), 3,4-dihydro-2H-pyran ( $\geq 97 \%)$, 2-tert-butylphenol ( $\geq 99 \%$ ), sodium dodecyl sulfate ( $\geq 99 \%$, SDS) were purchased from Sigma-Aldrich. Cesium hydroxide $(99.9 \%)$ was supplied by ABCR. [(tmeda)NiMe $]_{2}^{1}$, methoxymethyloxybenzene ${ }^{2}, 2-$ (2-bromophenoxy)tetrahydro-2H-pyran, ${ }^{3}$ 3,5-diperfluorohexylphenylboronic acid pinacol ester, ${ }^{4}$ and complexes $\mathbf{1}^{5}, \mathbf{2}^{6}$ and $\mathbf{4}^{7}$ were synthesized following reported procedures. Ethylene (grade 3.5) was supplied by Air Liquide and used as received. All other commercially available reagents and starting materials were supplied by Sigma Aldrich, Acros, ABCR or Activate Scientific. $\mathrm{CDCl}_{3}$ was supplied by Sigma Aldrich, all other deuterated solvents by Eurisotop.

\subsection{Analytical methods and techniques}

GPC was performed on a PolymerChar GPC-IR instrument equipped with PSS Polefin Linear XL columns $(3 \times 30 \mathrm{~cm}$, additional guard column), an infrared detector (IR5 MCT) and a fourcapillary viscometer at $160{ }^{\circ} \mathrm{C}$ in 1,2-dichlorobenzene and $1.0 \mathrm{~mL} \cdot \mathrm{min}^{-1}$ flow rate. A reduced flow rate of only $0.5 \mathrm{~mL} \cdot \mathrm{min}^{-1}$ was used for samples with $M_{\mathrm{n}}>10^{5} \mathrm{~g} \cdot \mathrm{mol}^{-1}$ to avoid sample shearing on the column. Sample molecular weights were analyzed via universal calibration employing narrow polystyrene standards (PSS Polymer Standards). The raw data was evaluated with PSS WinGPC UniChrom software. 
NMR spectra were recorded on a Bruker Avance III HD $400\left({ }^{1} \mathrm{H}: 400.1 \mathrm{MHz},{ }^{13} \mathrm{C}: 100.6 \mathrm{MHz}\right.$, ${ }^{19} \mathrm{~F}$ : $\left.376.1 \mathrm{MHz}\right)$, a Bruker Avance III 400 or a Bruker Avance III 600 spectrometer $\left({ }^{1} \mathrm{H}: 600\right.$ $\left.\mathrm{MHz},{ }^{13} \mathrm{C}: 151 \mathrm{MHz}\right) .{ }^{1} \mathrm{H}$ chemical shifts were referenced to the solvents' residual proton signals $\left(\mathrm{CDCl}_{3}: 7.26 \mathrm{ppm}, \mathrm{C}_{2} \mathrm{D}_{2} \mathrm{Cl}_{4}: 5.91 \mathrm{ppm}, \mathrm{C}_{6} \mathrm{D}_{6}: 7.16 \mathrm{ppm}\right) .{ }^{13} \mathrm{C}$ chemical shifts were referenced to the carbon signal of the deuterated solvent $\left(\mathrm{CDCl}_{3}\right.$ : $77.16 \mathrm{ppm}, \mathrm{C}_{2} \mathrm{D}_{2} \mathrm{Cl}_{4}: 74.30 \mathrm{ppm}, \mathrm{C}_{6} \mathrm{D}_{6}$ : $128.06 \mathrm{ppm}) .{ }^{19} \mathrm{~F}$ chemical shifts were referenced to external $\mathrm{BF}_{3} \cdot \mathrm{OEt}_{2}$. Multiplicities are reported as follows: s (singlet), d (doublet), t (triplet), q (quartet), quint. (quintet), p (pentet), vm (virtual multiplet), m (multiplet), br. (broad). NMR spectra of polyethylenes were recorded with addition of $5 \mathrm{mg} \mathrm{mL}^{-1}$ of $\mathrm{Cr}(\mathrm{acac})_{3}$ as paramagnetic relaxation agent.

DSC measurements were carried out on a Netzsch DSC 204 F1 instrument (software: Netzsch Proteus Thermal Analysis, version 6.1.0) on ca. $5 \mathrm{mg}$ of polymer with heating and cooling rates of $10 \mathrm{~K} \mathrm{~min}{ }^{-1}$ under a nitrogen atmosphere. Additional measurement to estimate chain disentanglement were performed with a heating/cooling rate of $1 \mathrm{~K} \mathrm{~min}^{-1}$ (only first heating cycle reported). Crystallinities were determined assuming a melt enthalpy of $293 \mathrm{~J} \mathrm{~g}^{-1}$ for $100 \%$ crystalline polyethylene.

Dynamic light scattering (DLS) was performed on diluted polyethylene dispersions using a Malvern Zetasizer Nano-ZS ZEN 3600 instrument $(633 \mathrm{~nm})$ in backscattering mode $\left(173^{\circ}\right)$ at $25^{\circ} \mathrm{C}$. The data was analyzed to yield particle size distributions and polydispersity indices (PDIs; dimensionless number between 0 and 1; 1 being highly polydisperse; determined from gradient of cumulants analysis) using the Malvern Zetasizer Software, version 7.12.

Transmission electron microscopy (TEM) images were recorded on a Zeiss Libra 120 EF-TEM instrument. Polyethylene dispersion samples were dialyzed versus demineralized water for two weeks using Spectra/Por Dialysis Membranes 2, MWCO 12-14 kD and TEM samples prepared by drop casting (diluted to $0.005 \mathrm{wt}-\%$ ) directly on the grid. TEM images were analyzed using Image SP viewer and ImageJ/Fiji software.

X-ray diffraction analysis was performed at $100 \mathrm{~K}$ on a STOE IPDS-II diffractometer, equipped with a graphite-monochromated radiation source $(\lambda=0.71073 \AA)$ and an image plate detection system. Crystals were placed on a fine glass fiber with grease or oil. The selection, integration and averaging procedure of the measured reflex intensities, the determination of the unit cell dimensions and a least-squares fit of the $2 \Theta$ values as well as data reduction, LP-correction and 
space group determination were performed using the X-Area software package delivered with the diffractometer. ${ }^{8}$ Using Olex $2^{9}$, the structure was solved with the ShelXT. ${ }^{10}$ Structure solution program using Intrinsic Phasing and refined with the olex2.refine ${ }^{11}$ refinement package using Gauss-Newton minimization. Graphical representation was created by the ORTEP-3 V2.02. for Windows XP software package. ${ }^{12}$

\section{Synthesis and characterization of catalyst precursor 3}

\subsection{Phosphinophenol 3c}

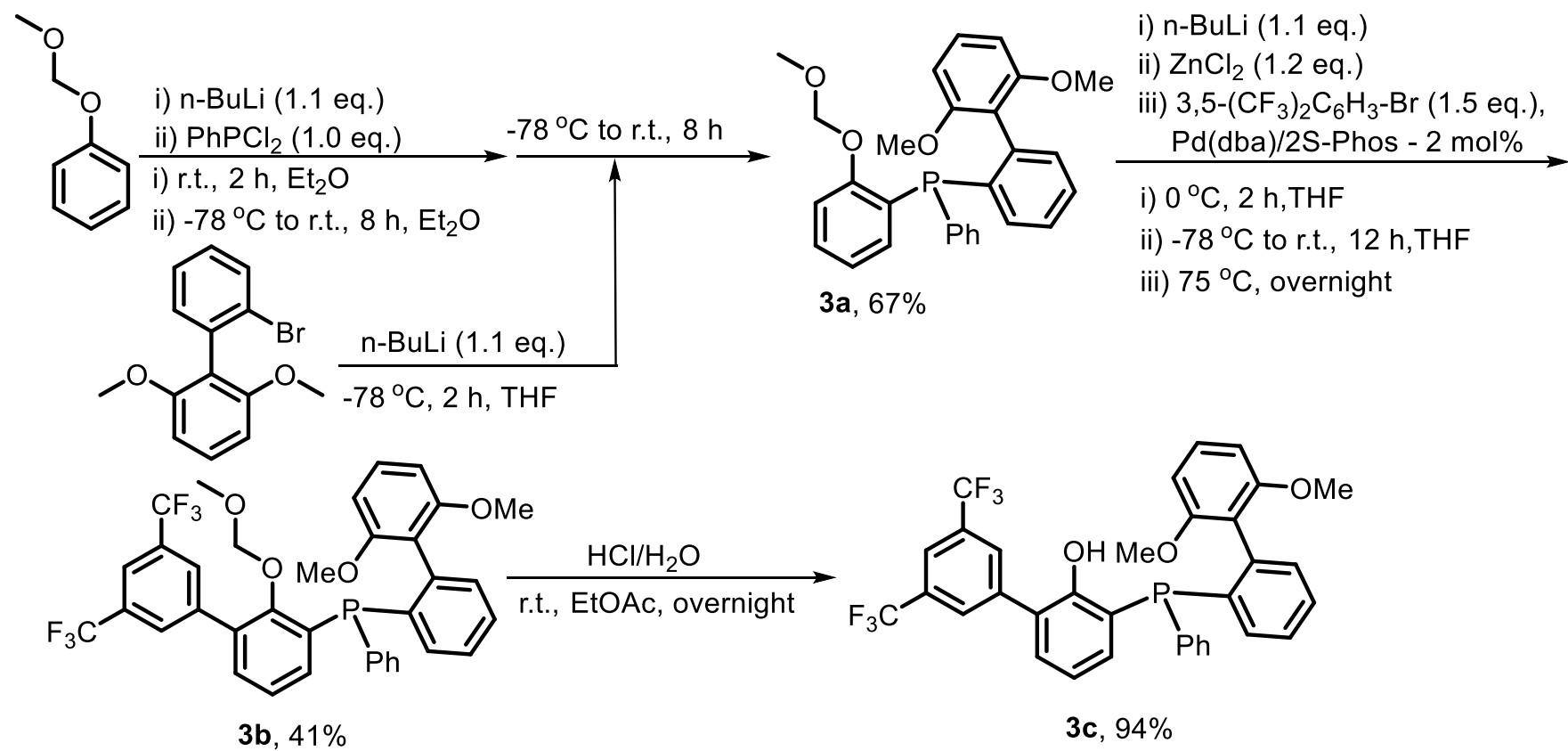

Scheme S1. Synthesis procedure for phosphinophenol 3c.

2- $\left\{2-\left[2^{\prime}, 6^{\prime}-(\mathrm{MeO})_{2} \mathrm{C}_{6} \mathrm{H}_{3}\right] \mathrm{C}_{6} \mathrm{H}_{4}\right\}(\mathrm{Ph}) \mathrm{P}_{-} \mathrm{C}_{6} \mathrm{H}_{4} \mathrm{OCH}_{2} \mathrm{OCH}_{3}$ (3a) was prepared by modification of a reported procedure $^{6}$ : At room temperature $\mathrm{n}-\mathrm{BuLi}(10 \mathrm{~mL}, 1.6 \mathrm{M}$ in hexane, $16 \mathrm{mmol}, 1.1$ equiv.) was added dropwise to a solution of methoxymethyloxybenzene (2.0 g, $14.5 \mathrm{mmol}, 1.0 \mathrm{equiv}$.) in diethyl ether $(30 \mathrm{~mL})$. The reaction mixture was stirred for 2 hours to yield a red suspension. The obtained suspension of 2-lithium-methoxymethyloxybenzene was added dropwise to a solution of $\mathrm{PhPCl}_{2}(2.5 \mathrm{~g}, 14.5 \mathrm{mmol}, 1.0$ equiv. $)$ in diethyl ether $(30 \mathrm{ml})$ at $-78{ }^{\circ} \mathrm{C}$. The mixture was 
warmed to room temperature slowly over 8 hours to afford a white suspension $\mathbf{A}$. In another Schlenk flask, n-BuLi (10 mL, 1.6 M in hexane, $16 \mathrm{mmol}, 1.1$ equiv) was added dropwise to a solution of 2'-bromo-2,6-dimethoxybiphenyl (4.2 g, $14.5 \mathrm{mmol}, 1.0$ equiv.) in THF (100 mL) at $-78{ }^{\circ} \mathrm{C}$. A white suspension $\mathbf{B}$ was obtained after 2 hours of stirring. Suspension A was added to suspension $\mathbf{B}$ at $-78{ }^{\circ} \mathrm{C}$, and the resulting reaction mixture was warmed to room temperature slowly over 8 hours. The mixture was concentrated and separated by column chromatography on silica using petrol ether/ethyl acetate $=10 / 1$ as eluent to afford pure 3a $(4.45 \mathrm{~g}, 9.7 \mathrm{mmol}, 67 \%)$.

${ }^{1} \mathrm{H}$ NMR (500 MHz, benzene-d $\left.6,300 \mathrm{~K}\right) \delta 7.45(\mathrm{ddd}, J=7.8,7.2,1.6 \mathrm{~Hz}, 2 \mathrm{H}), 7.42-7.35(\mathrm{~m}$, 2H), $7.18(\mathrm{td}, J=7.6,1.2 \mathrm{~Hz}, 1 \mathrm{H}), 7.12(\mathrm{t}, J=8.4 \mathrm{~Hz}, 1 \mathrm{H}), 7.10-7.00(\mathrm{~m}, 7 \mathrm{H}), 6.75(\mathrm{~d}, J=14.7$ $\mathrm{Hz}, 1 \mathrm{H}), 6.35$ (d, J = 8.3 Hz, 2H), $4.72-4.63$ (m, 2H, 2-H), 3.21 (s, 3H), 3.12 (s, 3H), 2.95 (s, $3 \mathrm{H})$.

${ }^{13} \mathrm{C}\left\{{ }^{1} \mathrm{H}\right\}$ NMR (126 MHz, benzene- $\left.d_{6}, 300 \mathrm{~K}\right) \delta 158.99(\mathrm{~d}, J=15.5 \mathrm{~Hz}), 158.34,158.06,142.19$, 141.92, $138.81(\mathrm{~d}, J=14.7 \mathrm{~Hz}), 138.03(\mathrm{~d}, J=10.7 \mathrm{~Hz}), 134.55,134.35,134.08(\mathrm{~d}, J=20.9 \mathrm{~Hz})$, $131.46(\mathrm{~d}, J=6.1 \mathrm{~Hz}), 129.44,128.88,128.52,128.31,127.07,121.80,119.74(\mathrm{~d}, J=7.6 \mathrm{~Hz})$, $113.57,103.66,103.48,93.95,55.42,54.83,54.58$.

${ }^{31} \mathrm{P}\left\{{ }^{1} \mathrm{H}\right\}$ NMR $\left(202 \mathrm{MHz}\right.$, benzene- $\left.d_{6}, 300 \mathrm{~K}\right) \delta-21.37$.

2- $\left\{2-\left[2^{\prime}, 6^{\prime}-(\mathrm{MeO})_{2} \mathrm{C}_{6} \mathrm{H}_{3}\right] \mathrm{C}_{6} \mathrm{H}_{4}\right\}(\mathrm{Ph}) \mathrm{P}-6-\left[3^{\prime}, 5^{\prime}-\left(\mathrm{CF}_{3}\right)_{2} \mathrm{C}_{6} \mathrm{H}_{3}\right]-\mathrm{C}_{6} \mathrm{H}_{3} \mathrm{OH}(3 \mathbf{c}):$ In a $50 \mathrm{~mL}$ Schlenk flask, n-BuLi (1.5 mL, 1.6 M in hexane, $2.4 \mathrm{mmol}, 1.1$ equiv.) was added dropwise to a solution of 3a $(1 \mathrm{~g}, 2.2 \mathrm{mmol})$ in $10 \mathrm{~mL}$ of THF at $0{ }^{\circ} \mathrm{C}$. The mixture was stirred for 2 hours at this temperature to give a red suspension. The latter was cooled to $-78{ }^{\circ} \mathrm{C}$, and solid $\mathrm{ZnCl}_{2}(0.36 \mathrm{~g}$, 2.6 mmol, 1.2 equiv.) was added. The reaction mixture was stirred at $-78{ }^{\circ} \mathrm{C}$ for three hours, during which a clear solution formed gradually. 1-Bromo-3,5-bis(trifluoromethyl)benzene (0.9 g, $3.1 \mathrm{mmol}, 1.5$ equiv.) was added followed by a mixture of [Pd(dba) 2$](0.025 \mathrm{~g}, 0.04 \mathrm{mmol}, 0.02$ equiv.) and Sphos (0.036 g, $0.08 \mathrm{mmol}, 0.04$ equiv.) in $5 \mathrm{~mL}$ of THF. After stirring for 16 hours at $75{ }^{\circ} \mathrm{C}$ the mixture was concentrated, and the residue was separated by column chromatography on silica using petrol ether/ethyl acetate $=20 / 1$ as eluent to yield pure $\mathbf{3 b}(0.6 \mathrm{~g}, 0.9 \mathrm{mmol}, 41 \%)$. 
The obtained $3 \mathbf{b}(0.5 \mathrm{~g}, 0.75 \mathrm{mmol})$ was dissolved in $10 \mathrm{~mL}$ of degassed ethyl acetate, and $2 \mathrm{~mL}$ of conc. aqueous $\mathrm{HCl}$ were added. After stirring at room temperature overnight, the mixture was added slowly into a solution of $5 \mathrm{~g} \mathrm{NaHCO}_{3}$ in $60 \mathrm{~mL}$ of water and stirred for 30 minutes. The organic phase was separated, and the aqueous phase was extracted with ethyl acetate $(2 \times 20 \mathrm{~mL})$. The combined organic phases were concentrated, and the residue was purified by column chromatography on silica using petrol ether/ethyl acetate $=20 / 1$ as eluent to give pure $\mathbf{3 c}(0.45 \mathrm{~g}$, $0.72 \mathrm{mmol}, 96 \%)$.

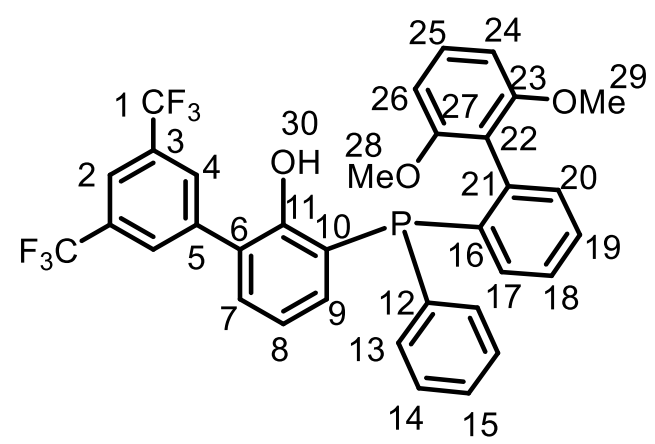

${ }^{1} \mathrm{H}$ NMR $\left(500 \mathrm{MHz}\right.$, benzene- $\left.d_{6}, 300 \mathrm{~K}\right) \delta 7.88(\mathrm{~s}, 2 \mathrm{H}, 4-\mathrm{H}), 7.66(\mathrm{~s}, 1 \mathrm{H}, 2-\mathrm{H}), 7.47-7.41(\mathrm{~m}, 1 \mathrm{H}$, 19-H), 7.32-7.27 (m, 2H, 13-H), $7.25\left(\mathrm{dd},{ }^{3} J_{H P}=7.6,4.5 \mathrm{~Hz}, 1 \mathrm{H}, 17-\mathrm{H}\right), 7.12\left(\mathrm{ddd},{ }^{3} J_{H P}=7.6\right.$ Hz, 1H, 9-H), 7.06 (dd, $J=8.3 \mathrm{~Hz}, 1 \mathrm{H}, 25-\mathrm{H}), 7.01-6.93$ (m, 5H, 14-H, 15-H, 7-H and 18-H), $6.79(\mathrm{dd}, J=7.6,1.5 \mathrm{~Hz}, 1 \mathrm{H}, 20-\mathrm{H}), 6.60(\mathrm{q}, J=7.6 \mathrm{~Hz}, 1 \mathrm{H}, 8-\mathrm{H}), 6.27$ (d, $J=8.3 \mathrm{~Hz}, 1 \mathrm{H}, 24$ or 26-H), 6.22 (d, $8.3 \mathrm{~Hz}, 1 \mathrm{H}, 24$ or 26-H),3.11 (s, 3H, 28 or 29-H), 3.03 (s, 3H, 28 or 29-H).

${ }^{13} \mathrm{C}\left\{{ }^{1} \mathrm{H}\right\}$ NMR (126 MHz, benzene- $\left.d_{6}, 300 \mathrm{~K}\right) \delta 158.11(\mathrm{C} 23$ or $\mathrm{C} 27), 157.66(\mathrm{C} 23$ or C27), $156.11\left(\mathrm{~d},{ }^{2} J_{C P}=21.6 \mathrm{~Hz}, \mathrm{C} 11\right), 142.40(\mathrm{C} 21), 140.13(\mathrm{C} 10), 140.77(\mathrm{C} 21), 134.89\left(\mathrm{~d},{ }^{3} J_{C P}=5.2\right.$ $\mathrm{Hz}, \mathrm{C} 20), 134.86\left(\mathrm{~d},{ }^{1} J_{C P}=10.6 \mathrm{~Hz}, \mathrm{C} 16\right), 134.83\left(\mathrm{~d},{ }^{2} J_{C P}=17.5 \mathrm{~Hz}, \mathrm{C} 9\right), 134.81\left(\mathrm{~d},{ }^{1} J_{C P}=11.3\right.$ Hz, C12), 133.62 (C19), 133.60 (d, $\left.{ }^{2} J_{C-P}=18.9 \mathrm{~Hz}, \mathrm{C} 13\right), 131.69$ (C17), 131.63 (d, ${ }^{3} J_{C P}=7.4 \mathrm{~Hz}$, C20), $131.10\left(\mathrm{q},{ }^{2} J_{C F}=32.9 \mathrm{~Hz}, \mathrm{C} 3\right), 129.77(\mathrm{C} 4), 129.48(\mathrm{C} 25), 128.41(\mathrm{C} 15), 128.36\left(\mathrm{~d},{ }^{2} J_{C P}=\right.$ $6.3 \mathrm{~Hz}, \mathrm{C} 14$ and C7), 128.06 (C18), 125.05 (C5), $124.16\left(\mathrm{~d},{ }^{3} J_{C P}=7.3 \mathrm{~Hz}, \mathrm{C} 6\right), 123.88\left(\mathrm{q},{ }^{1} J_{C F}=\right.$ $273.3 \mathrm{~Hz}, \mathrm{C} 1), 120.93(\mathrm{C} 8), 120.25$ (q, $\left.{ }^{3} J_{C F}=3.8 \mathrm{~Hz}, \mathrm{C} 2\right), 119.11$ (d, $\left.{ }^{3} J_{C P}=8.0 \mathrm{~Hz}, \mathrm{C} 22\right)$, $103.97(\mathrm{~d}, J=40.4 \mathrm{~Hz}, \mathrm{C} 24$ and C26), $54.92(\mathrm{~d}, J=20.6 \mathrm{~Hz}, \mathrm{C} 28$ and C29). 
${ }^{19} \mathrm{~F}\left\{{ }^{1} \mathrm{H}\right\}$ NMR (471 MHz, benzene- $\left.d_{6}, 300 \mathrm{~K}\right) \delta-62.39$.

${ }^{31} \mathrm{P}\left\{{ }^{1} \mathrm{H}\right\}$ NMR $\left(202 \mathrm{MHz}\right.$, benzene- $\left.d_{6}, 300 \mathrm{~K}\right) \delta-37.56$.

\subsection{Complex 3}

The following general procedure was applied for the synthesis of the pyridine complexes, exemplified here for 3: To $23 \mathrm{mg}$ [(tmeda)NiMe 2$]$ (110 $\mu \mathrm{mol}, 1.1$ equiv.) and $62 \mathrm{mg}$ phosphinophenol 3c (100 $\mu \mathrm{mol}, 1.0$ equiv.), a solution of pyridine (25 equiv.) in $5 \mathrm{~mL}$ of benzene was added. Gas evolution (methane) was observed, and the reaction mixture turned to yellow. After stirring for 4 hours at room temperature, volatiles were removed in vacuo. The residue was dispersed with benzene again, and any nickel black formed during the reaction was removed via centrifugation. The yellow solution was vitrified by cooling the flask with liquid nitrogen, and the solvent removed by freeze drying to yield the desired product $\mathbf{3}$ as a yellow powder (74 $\mathrm{mg}$, $95 \mu \mathrm{mol}, 95 \%)$.
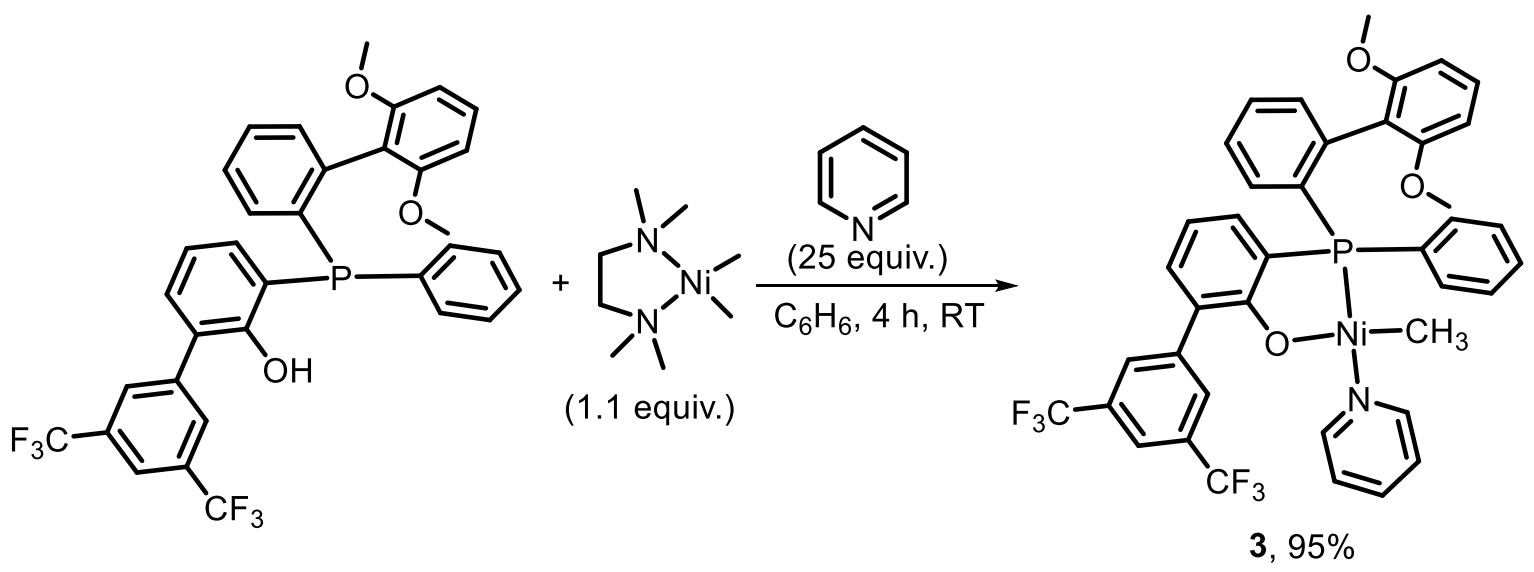

Scheme S2. Synthesis procedure for complexes, exemplified for 3. 


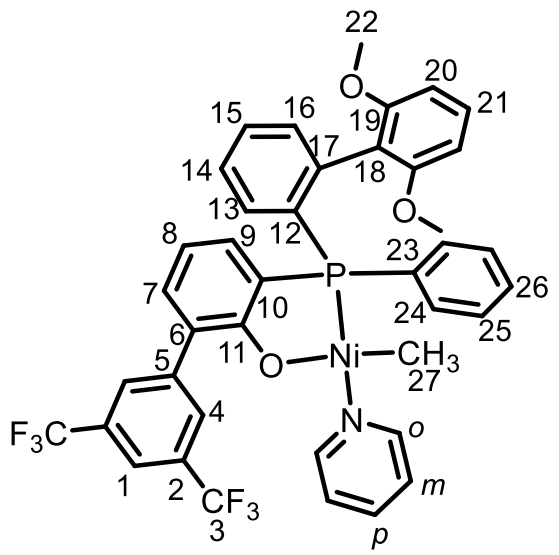

${ }^{1} \mathrm{H}$ NMR $\left(500 \mathrm{MHz}\right.$, benzene- $\left.d_{6}, 300 \mathrm{~K}\right) \delta 8.39$ (s, 2H, 4-H), 8.25 (d, ${ }^{3} J_{H H}=4.6 \mathrm{~Hz}, 2 \mathrm{H}$, o-Pyr), $7.75\left(\mathrm{ddd},{ }^{3} J_{H P}=9.9 \mathrm{~Hz},{ }^{3} J_{H H}=7.6 \mathrm{~Hz},{ }^{4} J_{H H}=1.7 \mathrm{~Hz}, 2 \mathrm{H}, 24-\mathrm{H}\right), 7.71(\mathrm{~s}, 1 \mathrm{H}, 1-\mathrm{H}), 7.61(\mathrm{dd}$, $\left.{ }^{3} J_{H H}=7.6 \mathrm{~Hz},{ }^{3} \mathrm{~J}_{\mathrm{HP}}=7.6 \mathrm{~Hz}, 1 \mathrm{H}, 13-\mathrm{H}\right), 7.41\left(\mathrm{dd},{ }^{3} J_{H H}=7.3, \mathrm{~J}=4.4 \mathrm{~Hz}, 1 \mathrm{H}, 16-\mathrm{H}\right), 7.30(\mathrm{dd}$, $\left.{ }^{3} J_{H H}=8.0 \mathrm{~Hz},{ }^{3} J_{H P}=8.0 \mathrm{~Hz}, 1 \mathrm{H}, 7-\mathrm{H}\right), 7.21(\mathrm{~m}, 2 \mathrm{H}, 21-\mathrm{H}$ and 15-H), 7.13-7.03 (m, 4H, 9-, 25and 26-H), $6.98\left(\mathrm{dd},{ }^{3} J_{\mathrm{HH}}=7.6 \mathrm{~Hz}, 1 \mathrm{H}, 14-\mathrm{H}\right), 6.87\left(\mathrm{t},{ }^{3} J_{H H}=7.5 \mathrm{~Hz}, 1 \mathrm{H}, \mathrm{p}-\mathrm{Pyr}\right), 6.60\left(\mathrm{dd},{ }^{3} J_{H H}=\right.$ 7.5, $6.5 \mathrm{~Hz}, 2 \mathrm{H}, \mathrm{m}-\mathrm{Pyr}), 6.47\left(\mathrm{dd},{ }^{3} J_{H H}=7.0 \mathrm{~Hz}, 1 \mathrm{H}, 8-\mathrm{H}\right), 6.39\left(\mathrm{~d},{ }^{3} J_{H H}=7.9 \mathrm{~Hz}, 1 \mathrm{H}, 20-\mathrm{H}\right)$, $6.37\left(\mathrm{~d},{ }^{3} J_{H H}=7.9 \mathrm{~Hz}, 1 \mathrm{H}, 20-\mathrm{H}\right), 3.35(\mathrm{~s}, 3 \mathrm{H}, 22-\mathrm{H}), 2.90(\mathrm{~s}, 3 \mathrm{H}, 22-\mathrm{H}),-0.70\left(\mathrm{~d},{ }^{3} J_{H P}=5.1 \mathrm{~Hz}\right.$, 3H, 27-H).

${ }^{13} \mathrm{C}\left\{{ }^{1} \mathrm{H}\right\}$ NMR $\left(126 \mathrm{MHz}\right.$, benzene- $\left.d_{6}, 300 \mathrm{~K}\right) \delta 173.44\left(\mathrm{~d},{ }^{3} J_{C P}=21.6 \mathrm{~Hz}, \mathrm{C} 11\right), 159.41(\mathrm{C} 19)$, 159.37 (C19), 150.27 (o-Pyr), 141.77 (d, $\left.{ }^{2} J_{C P}=17.1 \mathrm{~Hz}, \mathrm{C} 17\right), 136.42$ (p-Pyr), 135.53 (d, ${ }^{1} J_{C P}=$ $50.4 \mathrm{~Hz}, \mathrm{C} 23), 134.18$ (C13), $133.75(\mathrm{C} 7), 133.48\left(\mathrm{~d},{ }^{3} J_{\mathrm{CP}}=9.3 \mathrm{~Hz}, \mathrm{C} 16\right), 132.83\left(\mathrm{~d},{ }^{2} J_{C P}=9.6\right.$ $\mathrm{Hz}, \mathrm{C} 24), 132.41$ (C21), 132.37 (d, $\left.{ }^{2} J_{C P}=7.9 \mathrm{~Hz}, \mathrm{C} 9\right), 132.24$ (d, $\left.{ }^{1} J_{C P}=49.6 \mathrm{~Hz}, \mathrm{C} 12\right), 130.70$ $\left(\mathrm{q},{ }^{2} \mathrm{~J}_{\mathrm{CF}}=32.4 \mathrm{~Hz}, \mathrm{C} 2\right), 130.27(\mathrm{C} 15), 128.89(\mathrm{C} 4), 128.56\left(\mathrm{~d},{ }^{3} J_{C P}=9.3 \mathrm{~Hz}, \mathrm{C} 25\right), 128.52(\mathrm{C} 26)$, $126.81\left(\mathrm{~d},{ }^{3} J_{C P}=7.1 \mathrm{~Hz}, \mathrm{C} 14\right), 125.63(\mathrm{C} 5), 125.36\left(\mathrm{~d},{ }^{3} J_{C P}=9.9 \mathrm{~Hz}, \mathrm{C} 6\right), 124.58\left(\mathrm{q},{ }^{1} \mathrm{~J}_{\mathrm{CF}}=\right.$ 273.4 Hz, C3), 123.44 (m-Pyr), $123.20\left(\mathrm{~d},{ }^{1} J_{C P}=49.6 \mathrm{~Hz}, \mathrm{C} 10\right), 119.77$ (d, $\left.{ }^{3} J_{C P}=5.5 \mathrm{~Hz}, \mathrm{C} 18\right)$, $118.81(\mathrm{C} 1), 114.17\left(\mathrm{~d},{ }^{3} J_{H P}=7.3 \mathrm{~Hz}, \mathrm{C} 8\right), 103.32$ (C20), 103.14 (C20), 54.92 (C22), 54.24 (C22), $-13.67\left(\mathrm{~d},{ }^{2} J_{C P}=37.0 \mathrm{~Hz}, \mathrm{C} 27\right)$.

${ }^{19} \mathrm{~F}\left\{{ }^{1} \mathrm{H}\right\}$ NMRC NMR (471 MHz, benzene- $\left.d_{6}\right) \delta-62.06$.

${ }^{31} \mathrm{P}\left\{{ }^{1} \mathrm{H}\right\}$ NMR (202 MHz, benzene- $\left.d_{6}\right) \delta$ 21.55. 


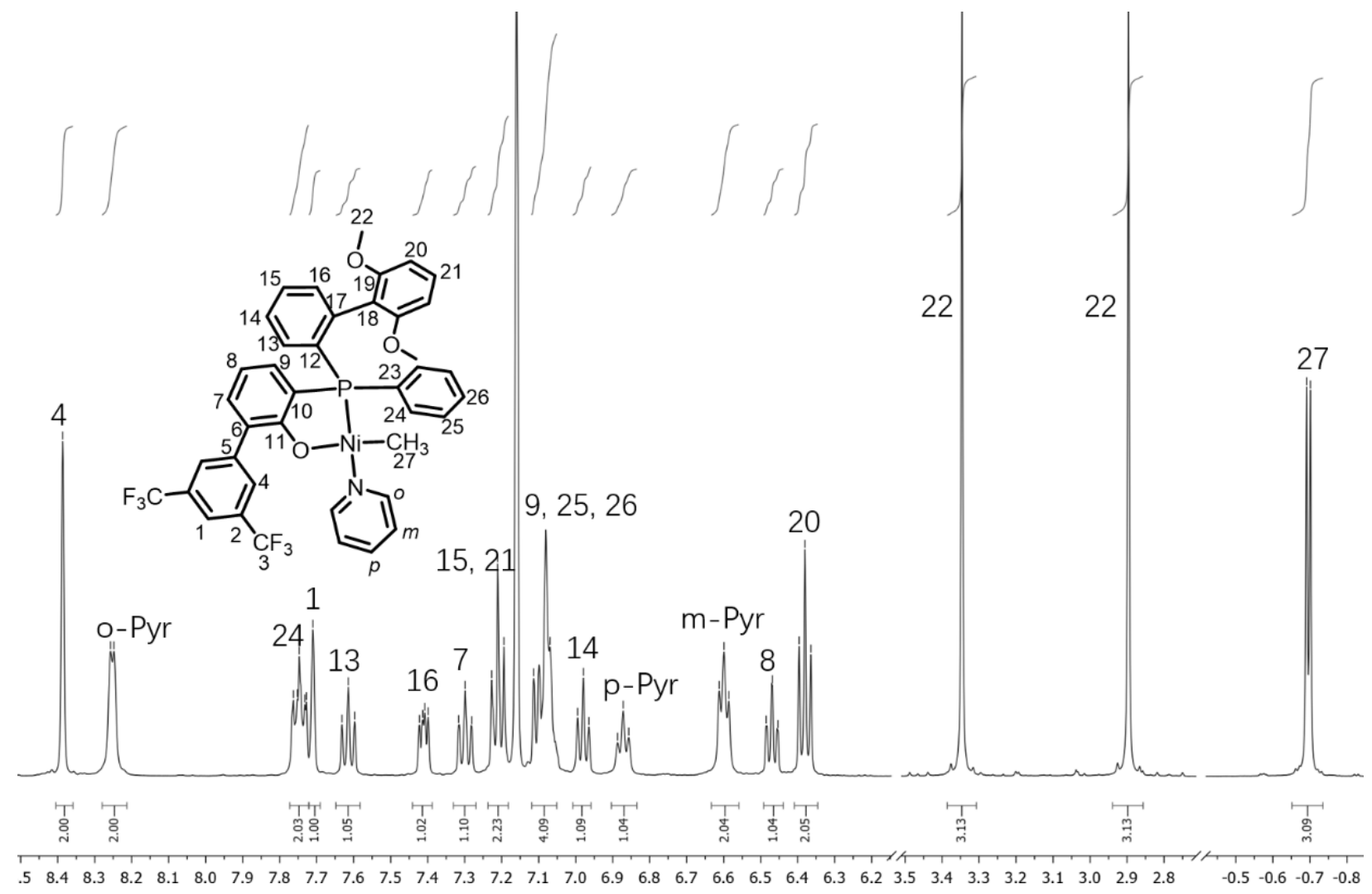

Figure S1. ${ }^{1} \mathrm{H}$ NMR spectrum of complex 3 in $\mathrm{C}_{6} \mathrm{D}_{6}$ at $300 \mathrm{~K}$. 

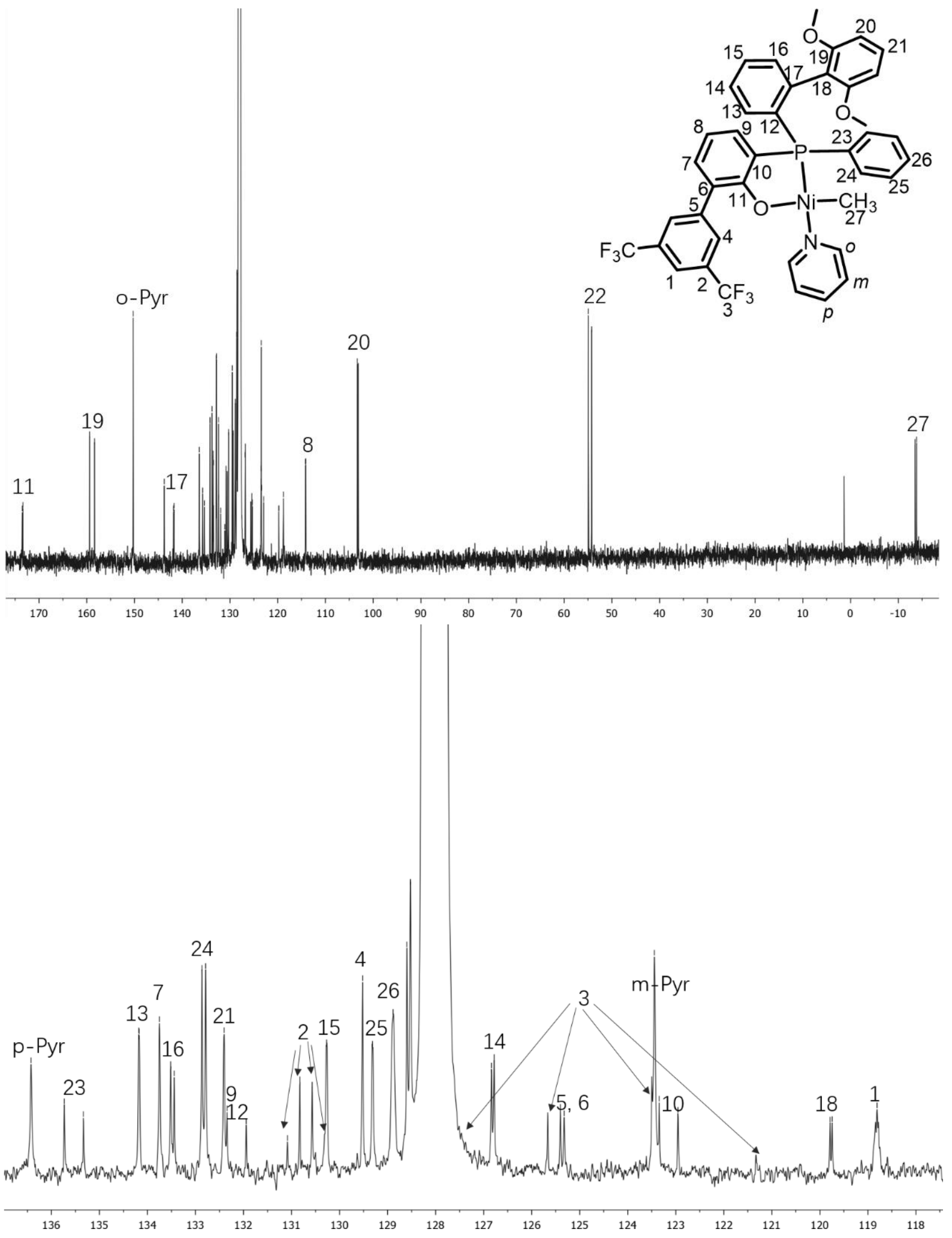

Figure S2. ${ }^{13} \mathrm{C}\left\{{ }^{1} \mathrm{H}\right\}$ NMR spectrum of complex 3 in $\mathrm{C}_{6} \mathrm{D}_{6}$ at $300 \mathrm{~K}$ (top) and details of aromatic regime (bottom). 


\section{Exposure of catalyst precursors to 1-hexanol}

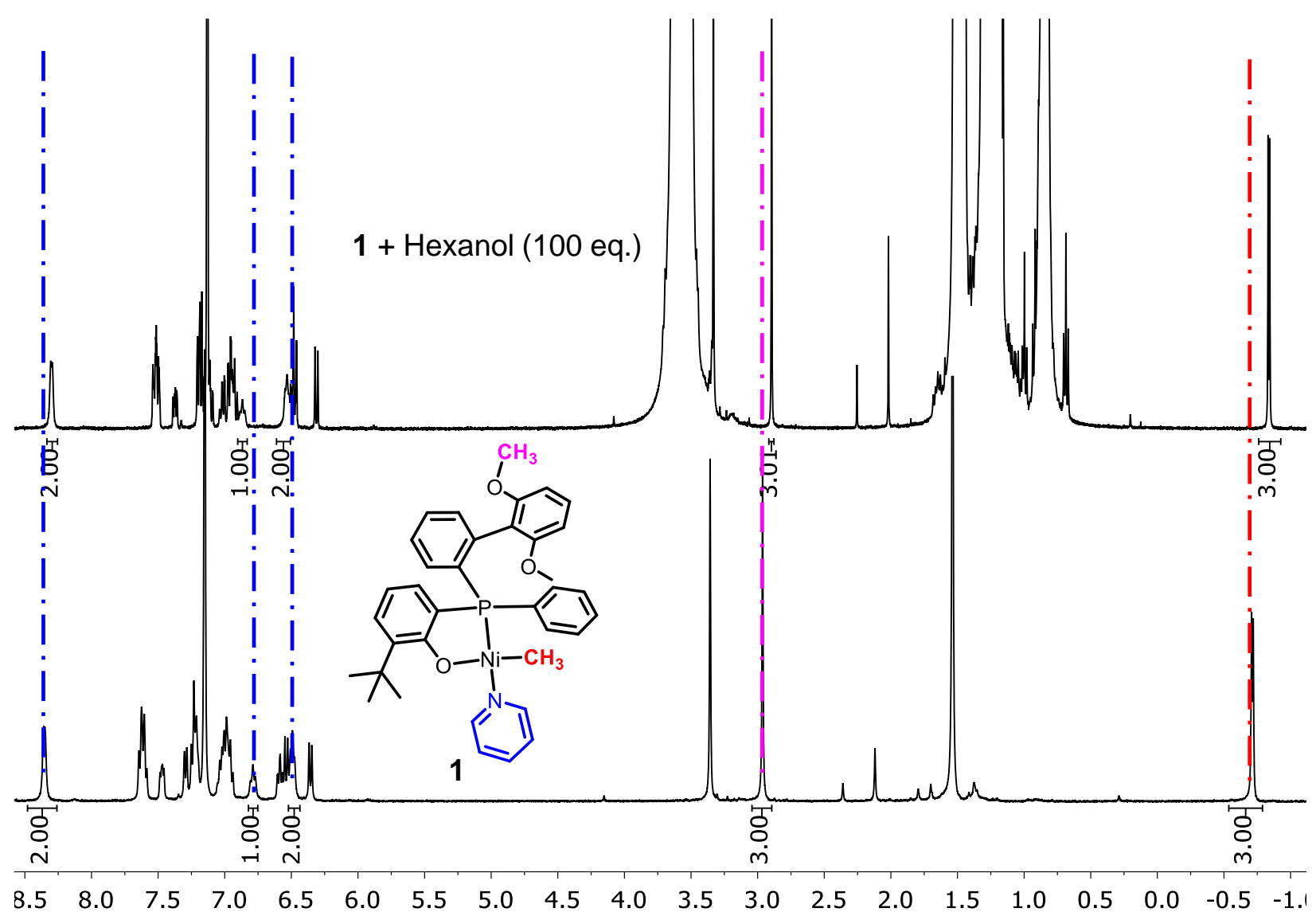

Figure S3. ${ }^{1} \mathrm{H}$ NMR spectrum (Benzene- $d_{6}, 400 \mathrm{MHz}, 25^{\circ} \mathrm{C}$ ) of $\mathbf{1}$ (bottom) and after addition of 1-hexanol (100 equiv.) and exposure for three hours (top). Slight changes of the shifts may arise from competitive coordination of hexanol with pyridine to the Ni center, or alteration of the solvent nature by 1-hexanol. 


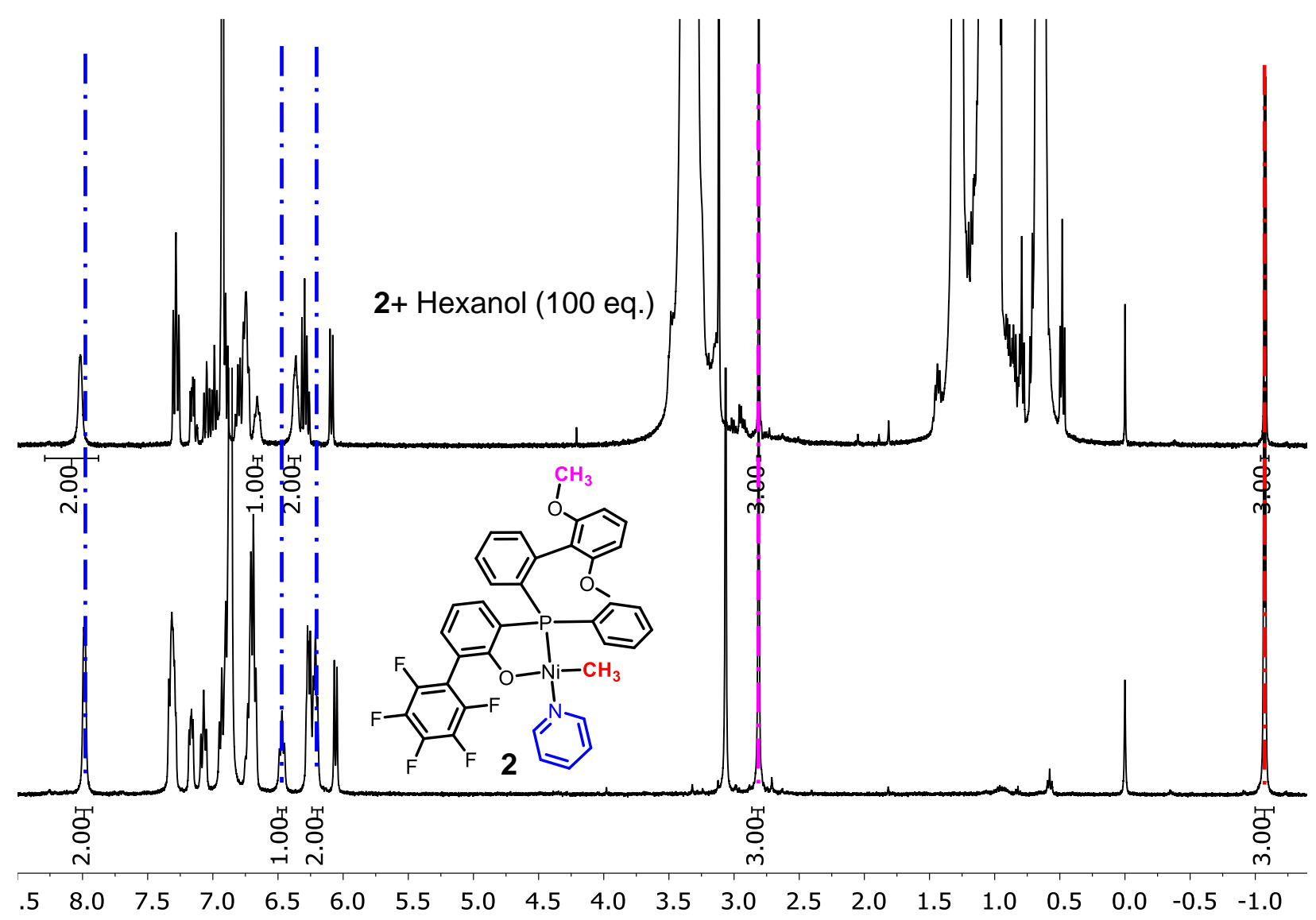

Figure S4. ${ }^{1} \mathrm{H}$ NMR spectrum (Benzene- $d_{6}, 400 \mathrm{MHz}, 25{ }^{\circ} \mathrm{C}$ ) of 2 before (bottom) and after addition of 1-hexanol (100 equiv.) and exposure for three hours (top). Slight changes of the shifts may arise from competitive coordination of hexanol with pyridine to the Ni center, or alteration of the solvent nature by 1-hexanol. 


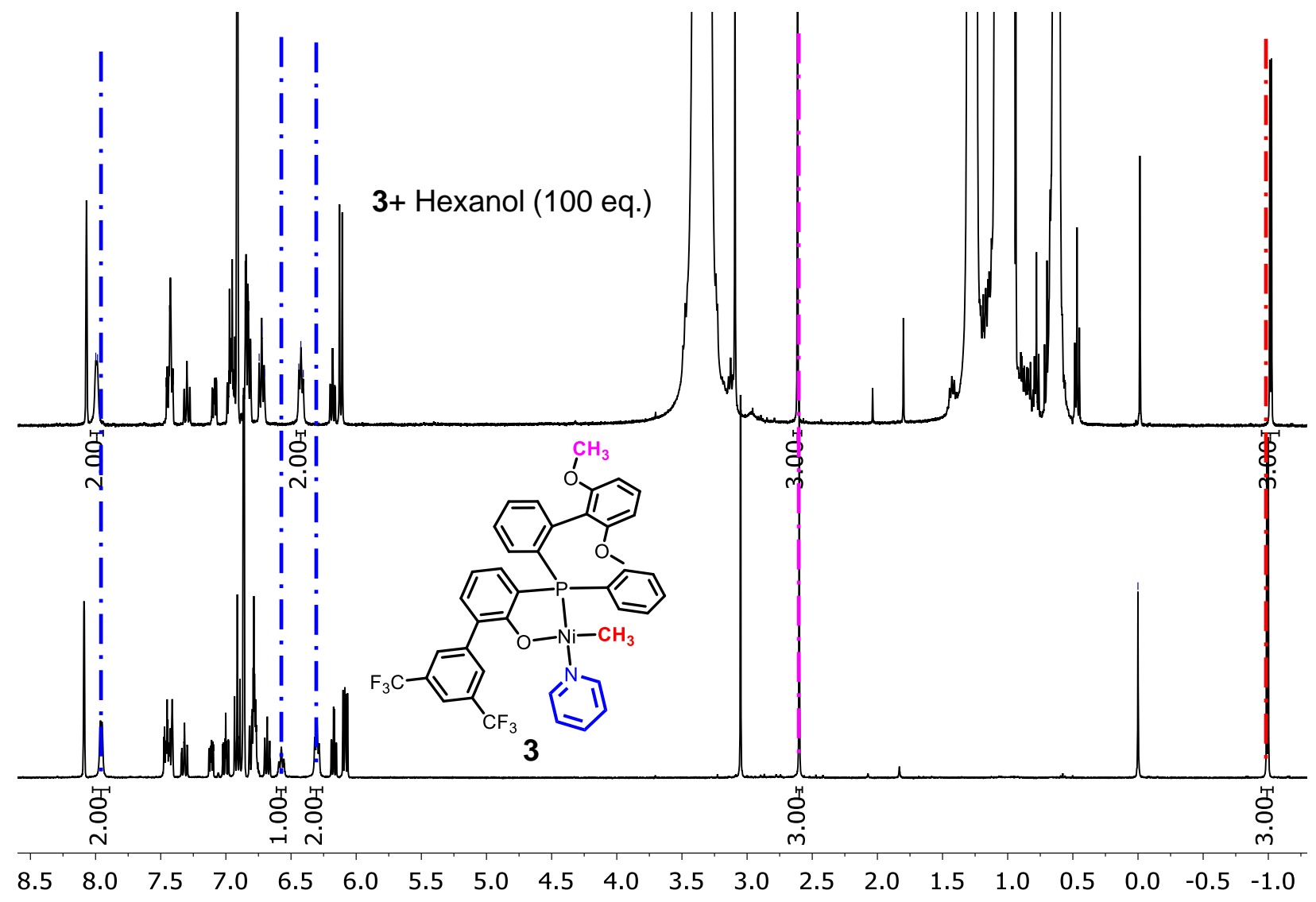

Figure S5. ${ }^{1} \mathrm{H}$ NMR spectrum (Benzene- $d_{6}, 400 \mathrm{MHz}, 25{ }^{\circ} \mathrm{C}$ ) of $\mathbf{3}$ before (bottom) and after addition of 1-hexanol (100 equiv.) and exposure for three hours (top). Slight changes of the shifts may arise from competitive coordination of hexanol with pyridine to the Ni center, or alteration of the solvent nature by 1-hexanol. 


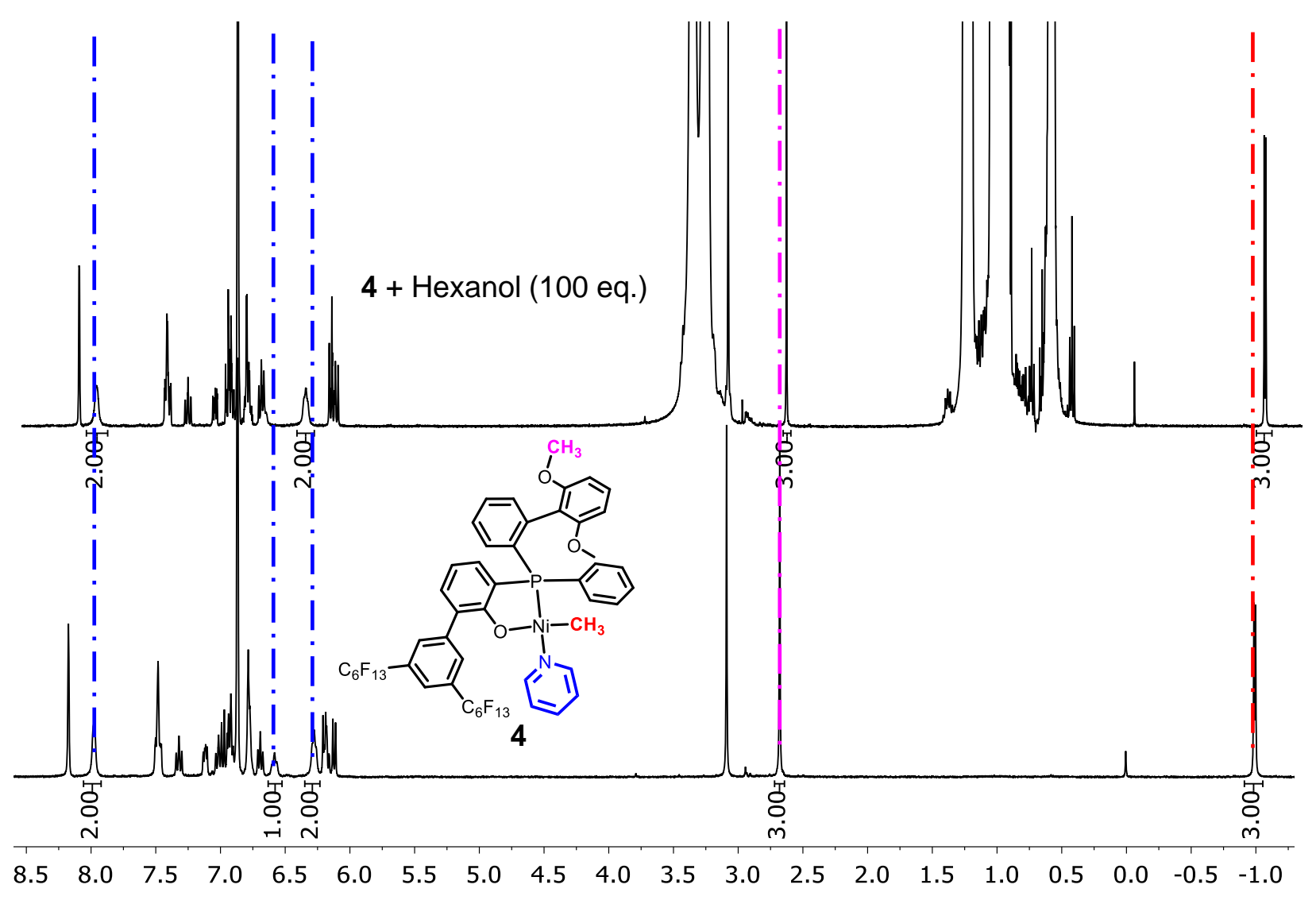

Figure S6. ${ }^{1} \mathrm{H}$ NMR spectrum (Benzene- $d_{6}, 400 \mathrm{MHz}, 25^{\circ} \mathrm{C}$ ) of $\mathbf{4}$ before (bottom) and after addition of 1-hexanol (100 equiv.) and exposure for three hours (top). Slight changes of the shifts may arise from competitive coordination of hexanol with pyridine to the Ni center, or alteration of the solvent nature by 1-hexanol. 


\section{Crystallographic data}

A suitable crystal of $\mathbf{3}$ was selected and placed on the diffractometer. The crystal was kept at 100

$\mathrm{K}$ during data collection.

Table S1. Crystal data and structure refinement for precursor 3 .

Identification code

Empirical formula

Formula weight

Temperature/K

Crystal system

Space group

$\mathrm{a} / \AA$

$\mathrm{b} / \AA$

c/

$\alpha /{ }^{\circ}$

$\beta /{ }^{\circ}$

$\gamma /{ }^{\circ}$

Volume $/ \AA^{3}$

Z

$\rho_{\text {calc } g / \mathrm{cm}^{3}}$

$\mu / \mathrm{mm}^{-1}$

$\mathrm{F}(000)$

Crystal size $/ \mathrm{mm}^{3}$

Radiation

$2 \Theta$ range for data collection/ ${ }^{\circ}$

Index ranges

Reflections collected

Independent reflections

Data/restraints/parameters

Goodness-of-fit on $\mathrm{F}^{2}$

Final $\mathrm{R}$ indexes $[\mathrm{I}>=2 \sigma(\mathrm{I})]$

Final $\mathrm{R}$ indexes [all data]

Largest diff. peak/hole / e $\AA^{-3}$
CCDC number-2111789

$\mathrm{C}_{40} \mathrm{H}_{32} \mathrm{~F}_{6} \mathrm{NNiO}_{3} \mathrm{P}$

778.34

100.0

triclinic

P-1

9.678(5)

$13.926(8)$

14.514(7)

70.73(4)

$72.30(4)$

$83.40(4)$

1758.9(17)

2

1.470

0.669

800.0

$0.5 \times 0.267 \times 0.1$

Mo Ka $(\lambda=0.71073)$

5.438 to 53.484

$-12 \leq \mathrm{h} \leq 12,-17 \leq \mathrm{k} \leq 17,-18 \leq 1 \leq 18$

14788

$7401\left[R_{\text {int }}=0.0406, R_{\text {sigma }}=0.0425\right]$

$7401 / 0 / 472$

1.051

$\mathrm{R}_{1}=0.0490, \mathrm{wR}_{2}=0.1300$

$\mathrm{R}_{1}=0.0622, \mathrm{wR}_{2}=0.1419$

$0.58 /-1.06$ 


\section{Ethylene polymerization procedure and polymer analysis}

\subsection{Aqueous ethylene polymerization procedure}

All polymerizations in water were conducted in a Büchi miniclave reactor with a $200 \mathrm{~mL}$ vessel equipped with a heating and cooling jacket connected to a thermostat, a mechanical stirrer, a nitrogen/vacuum supply and a thermocouple dipping into the reaction mixture. A Bronkhorst MassFlow apparatus consisting of two flow meters (up to $15 \mathrm{~g} \mathrm{~h}^{-1}$ and $150 \mathrm{~g} \mathrm{~h}^{-1}$ ethylene), a pressure meter and a compressed air-driven badger valve was used to work under constant ethylene pressure. Prior to all polymerization experiments, the reactor was evacuated and heated (thermostat temperature: $90^{\circ} \mathrm{C}$ ). When the internal reactor temperature was $>60{ }^{\circ} \mathrm{C}$, the reactor was flushed with nitrogen, evacuated three times and automatically cooled down to the desired reaction temperature. The desired amount of sodium dodecyl sulfate, cesium hydroxide and a magnetic stir bar were placed in a Schlenk flask, and water was added under vigorous stirring via cannula transfer. After the surfactant and base were dissolved completely, the desired amount of hexanol was added and the mixture was stirred for several minutes to afford a transparent solution. In a glovebox, $5 \mu \mathrm{mol}$ of catalyst precursor was dissolved in $1 \mathrm{~mL}$ of toluene, brought outside the glovebox and injected into the aforementioned aqueous solution in the Schlenk flask. Gentle stirring for 2 minutes afforded a clear pale-yellow single phase solution. This was transferred to the reactor and stirred at $1000 \mathrm{rpm}$. The reactor was pressurized with ethylene and brought to the desired temperature. During the polymerization experiment, constant presssure was applied. After the desired reaction time, the pressure was released stepwise. Below 15 bar residual pressure, the reactor was vented manually into a beaker to collect migrating dispersion due to foaming. The entire dispersion was weighed, filtered over cotton wool and the solids content was determined by precipitation of a $50 \mathrm{~g}$ aliquot of dispersion in $300 \mathrm{~mL}$ of methanol. After stirring for 30 minutes, the precipitated bulk polymer was filtered and washed thoroughly with water and methanol and dried in a vacuum oven $\left(60^{\circ} \mathrm{C}, 30 \mathrm{mbar}\right)$ overnight. 


\subsection{NMR analysis}
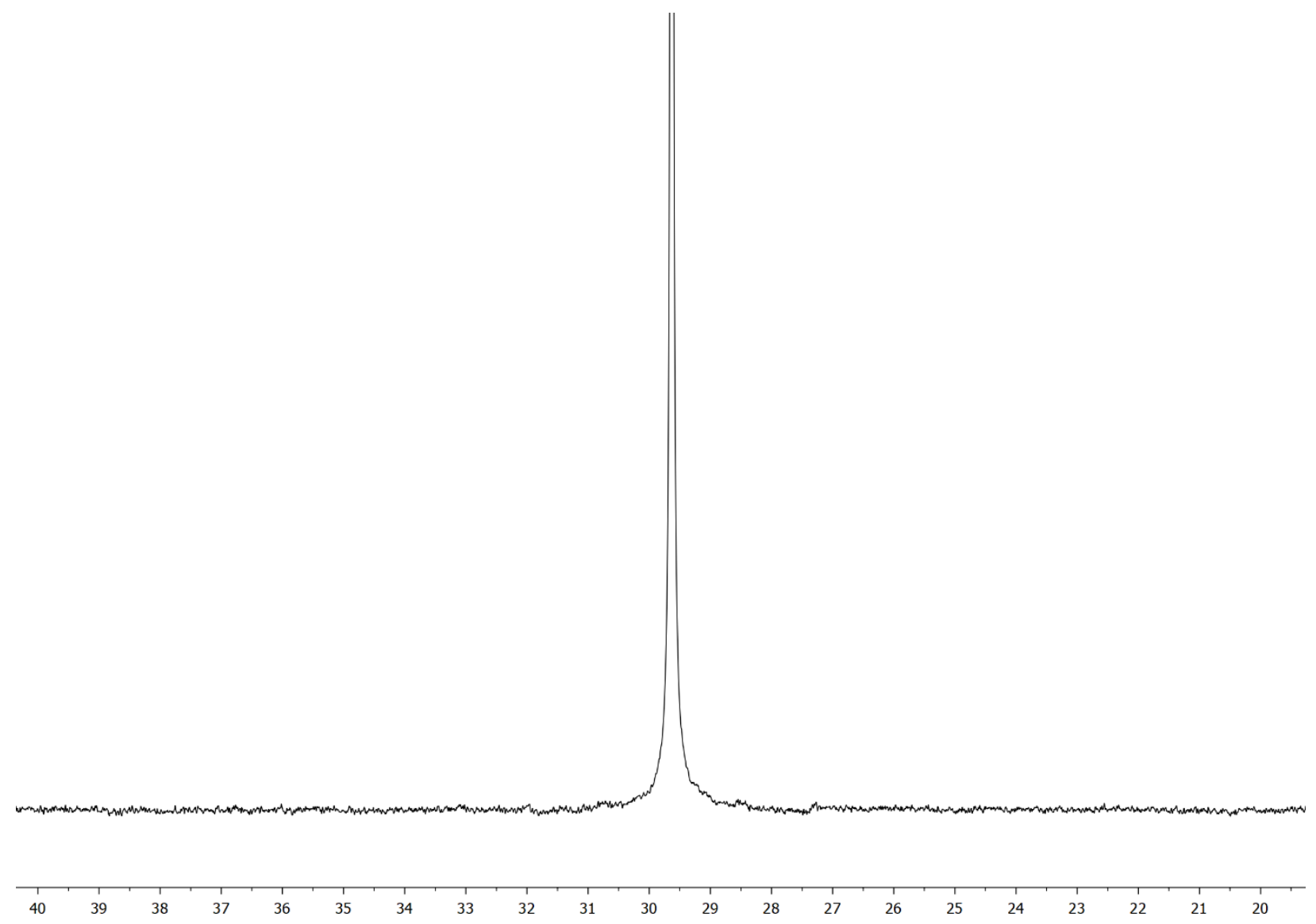

Figure S7. ${ }^{13} \mathrm{C}\left\{{ }^{1} \mathrm{H}\right\}$ NMR spectrum $\left(101 \mathrm{MHz}, \mathrm{C}_{2} \mathrm{D}_{2} \mathrm{Cl}_{4}, 120{ }^{\circ} \mathrm{C}\right)$ of polyethylene obtained (Table 1, entry 5). 


\subsection{DSC traces}

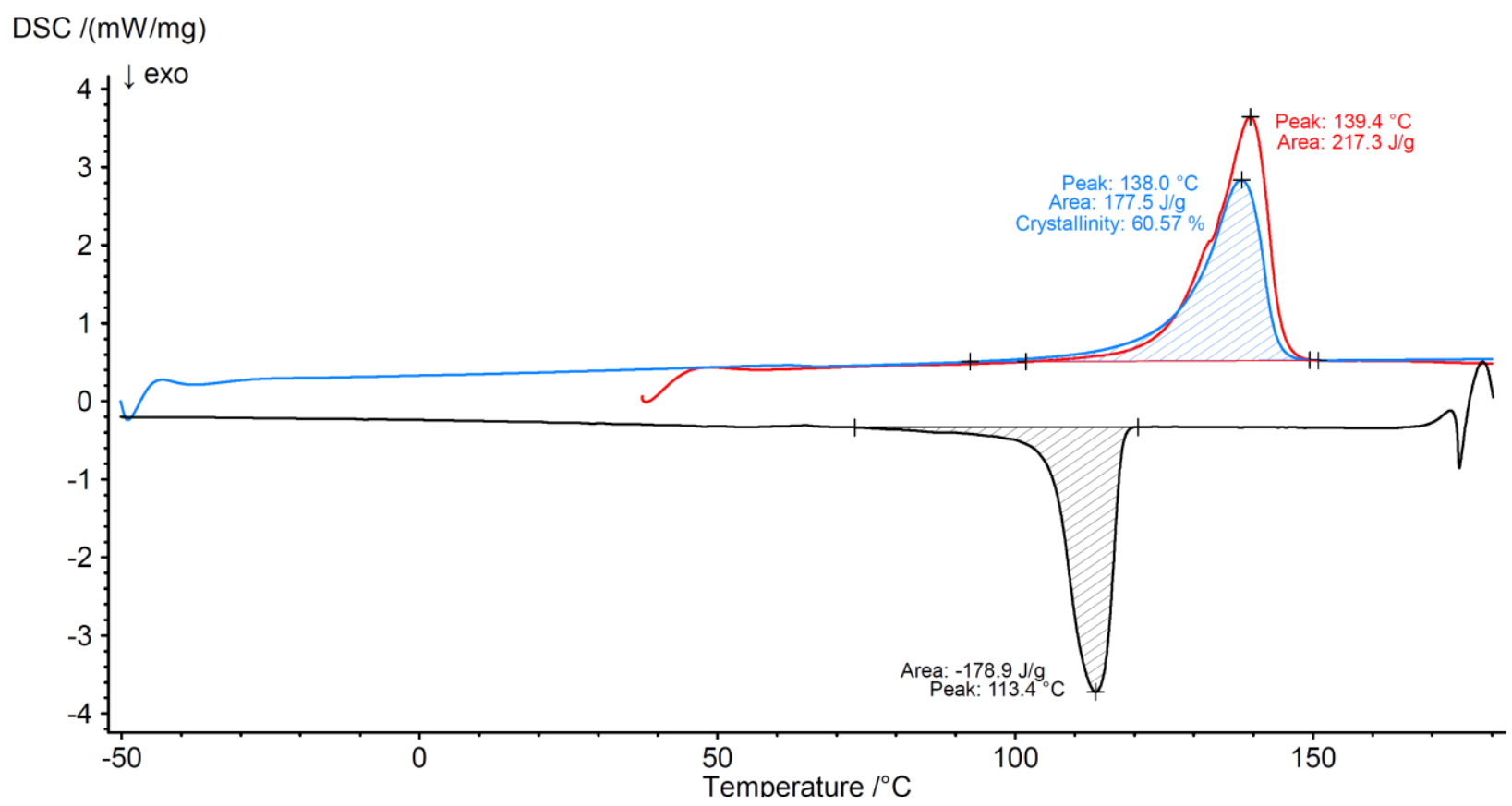

DSC /(mW/mg)

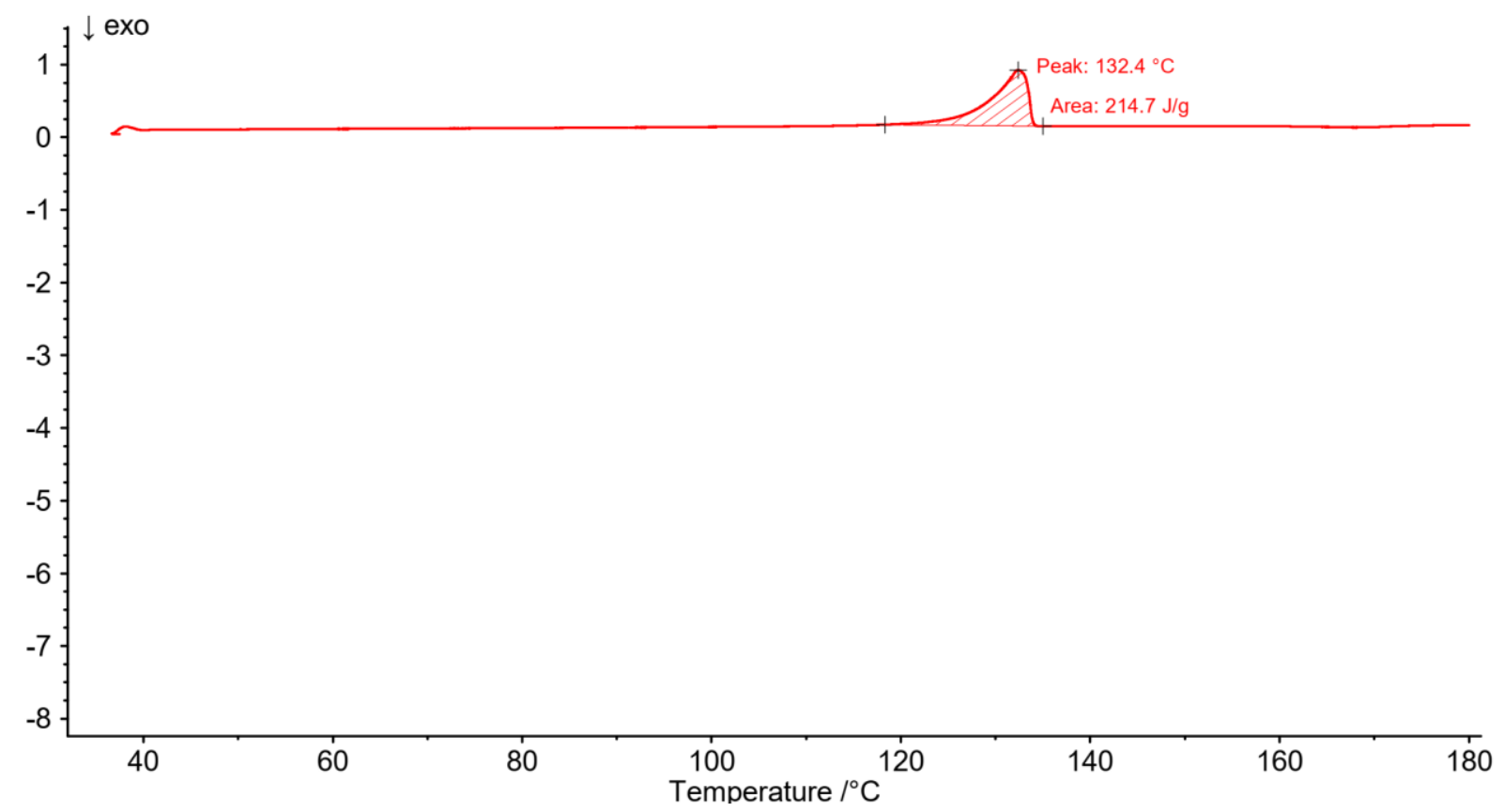

Figure S8. DSC traces of polyethylene obtained (Table 1, entry 5). Top: measured with $10 \mathrm{~K}$ $\min ^{-1}$ heating rate (red curve: $1^{\text {st }}$ heating; black curve: $1^{\text {st }}$ cooling; blue curve: $2^{\text {nd }}$ heating). Bottom: measured with $1 \mathrm{~K} \mathrm{~min}^{-1}$ (only $1^{\text {st }}$ heating shown). 


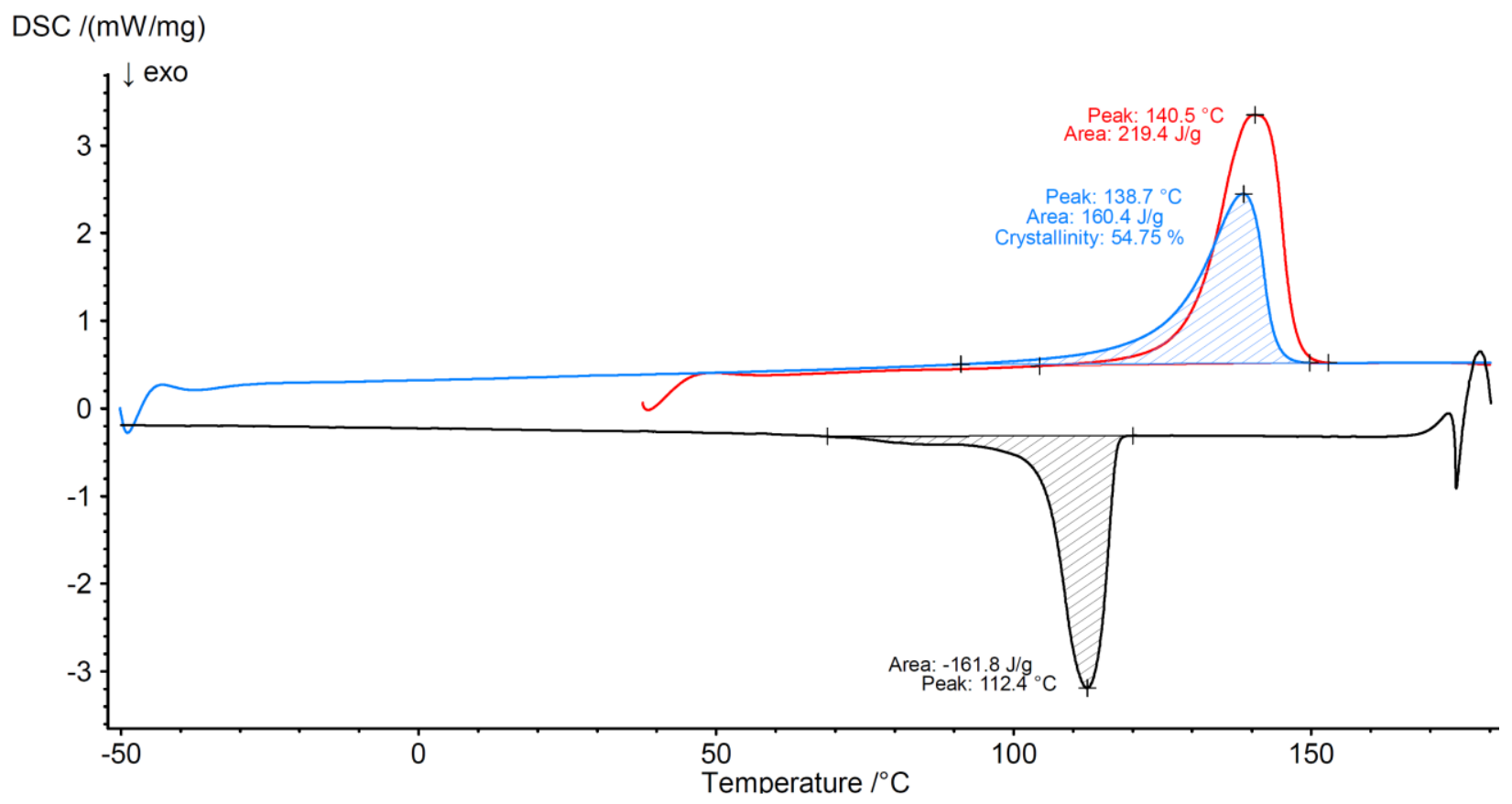

$\mathrm{DSC} /(\mathrm{mW} / \mathrm{mg})$

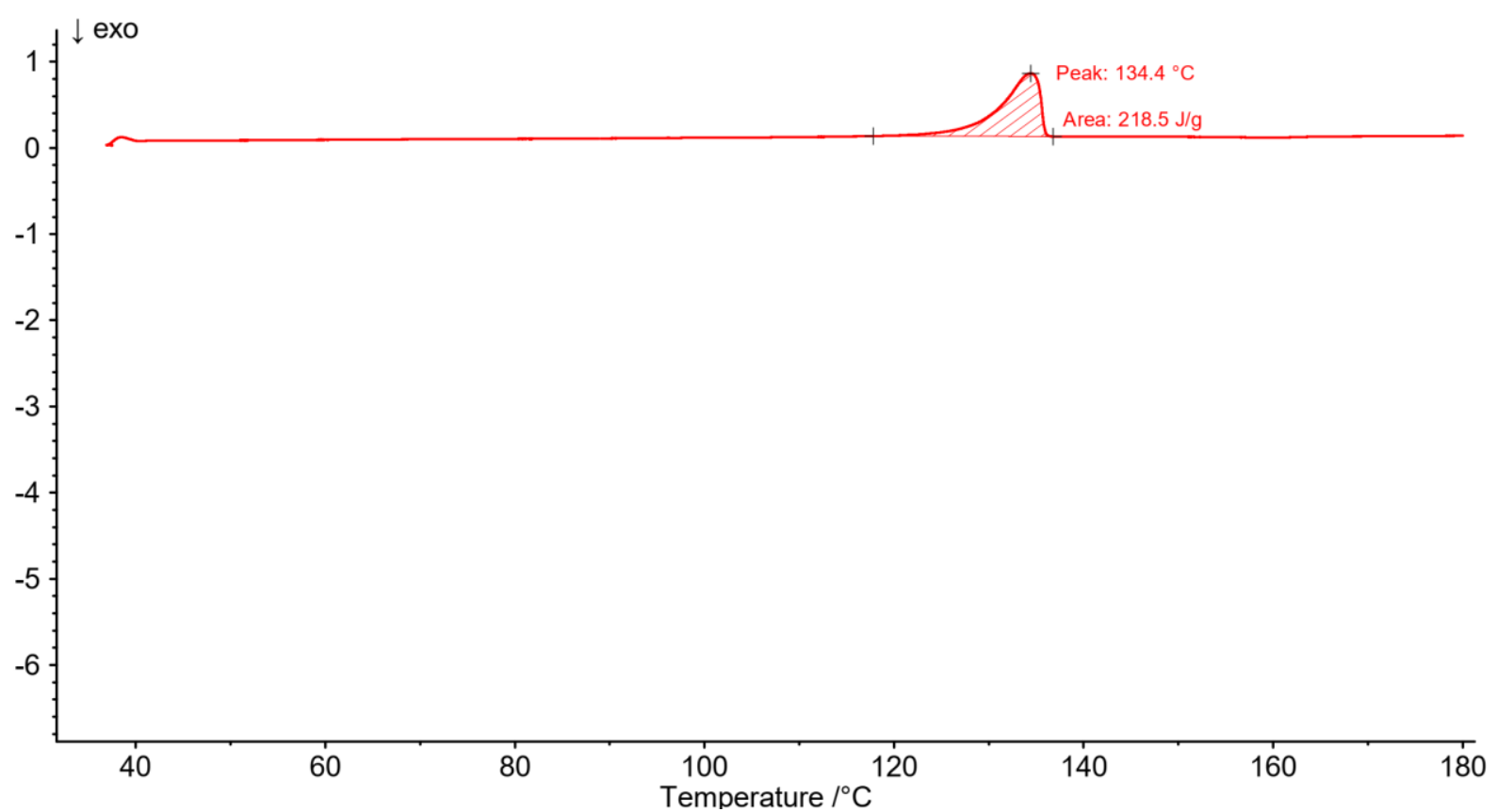

Figure S9. DSC traces of polyethylene obtained (Table 1, entry 6). Top: measured with $10 \mathrm{~K}$ $\min ^{-1}$ heating rate (red curve: $1^{\text {st }}$ heating; black curve: $1^{\text {st }}$ cooling; blue curve: $2^{\text {nd }}$ heating). Bottom: measured with $1 \mathrm{~K} \mathrm{~min}^{-1}$ (only $1^{\text {st }}$ heating shown). 


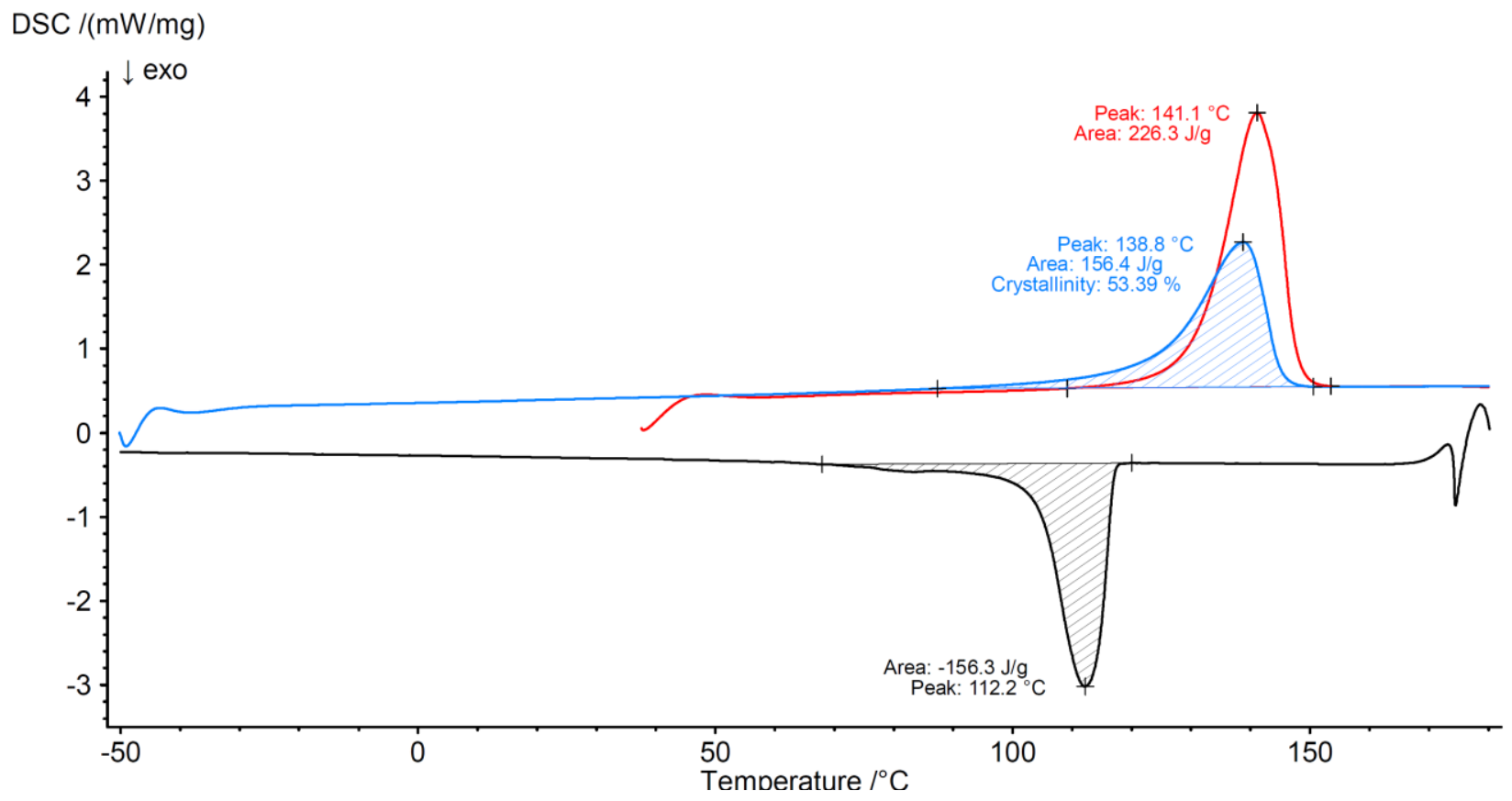

$\mathrm{DSC} /(\mathrm{mW} / \mathrm{mg})$

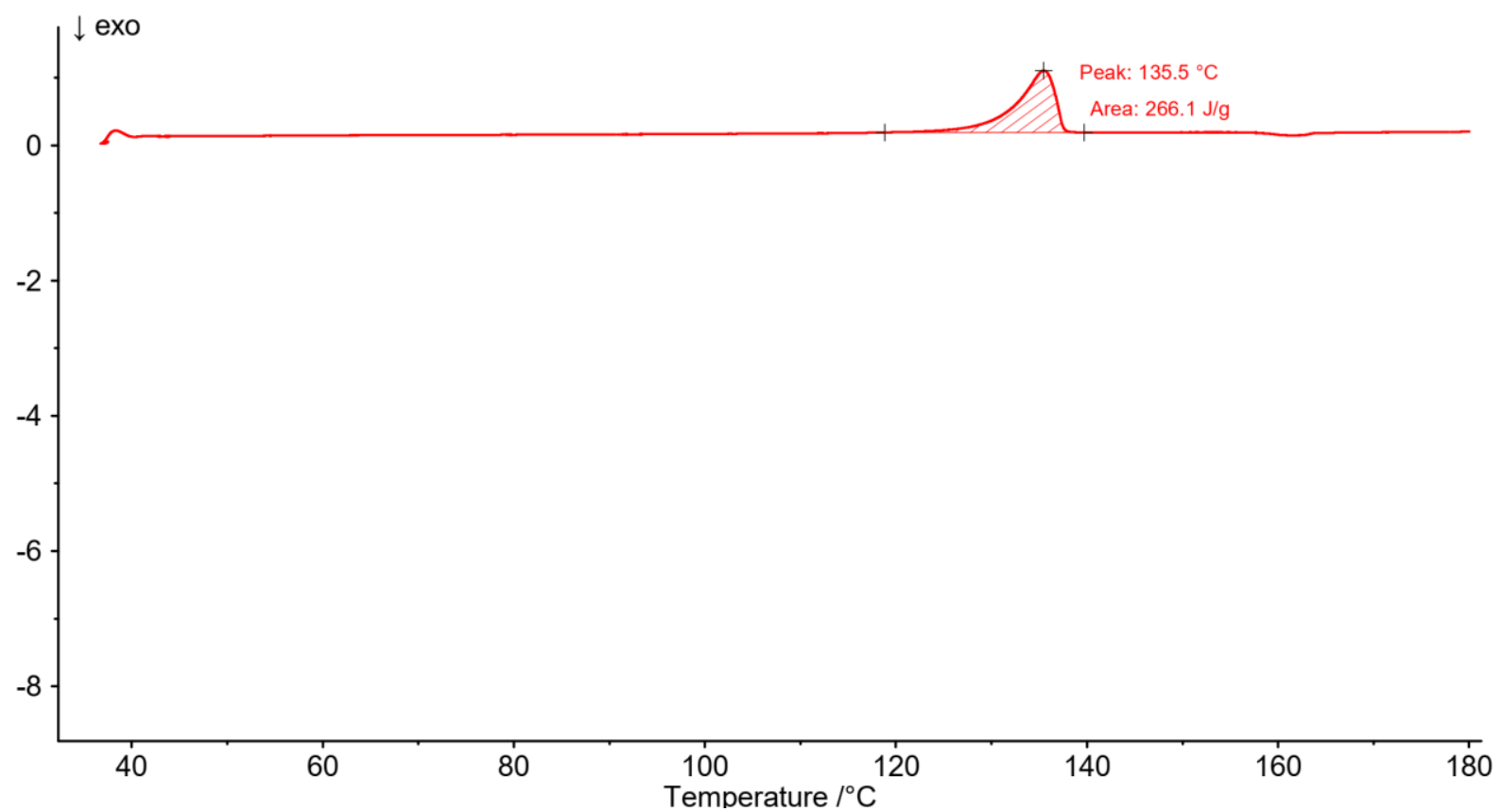

Figure S10. DSC traces of polyethylene obtained (Table 1, entry 7). Top: measured with $10 \mathrm{~K}$ $\min ^{-1}$ heating rate (red curve: $1^{\text {st }}$ heating; black curve, $1^{\text {st }}$ cooling; blue curve: $2^{\text {nd }}$ heating). Bottom: measured with $1 \mathrm{~K} \mathrm{~min}^{-1}$ (only $1^{\text {st }}$ heating shown). 

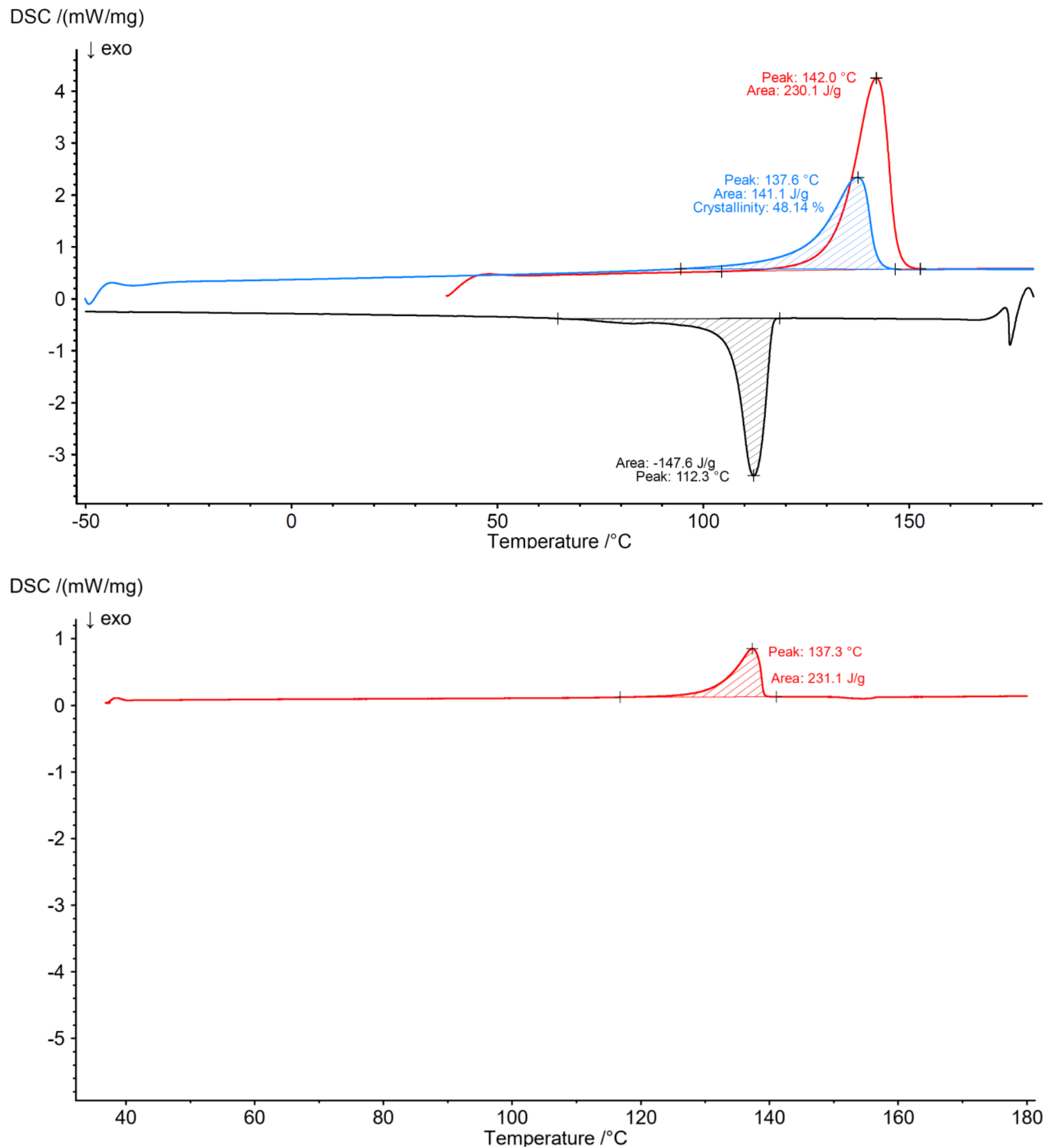

Figure S11. DSC trace of polyethylene obtained (Table 1, entry 8). Top: measured with $10 \mathrm{~K}$ $\min ^{-1}$ heating rate (red curve: $1^{\text {st }}$ heating; black curve: $1^{\text {st }}$ cooling; blue curve: $2^{\text {nd }}$ heating). Bottom: measured with $1 \mathrm{~K} \mathrm{~min}^{-1}$ (only $1^{\text {st }}$ heating shown). 


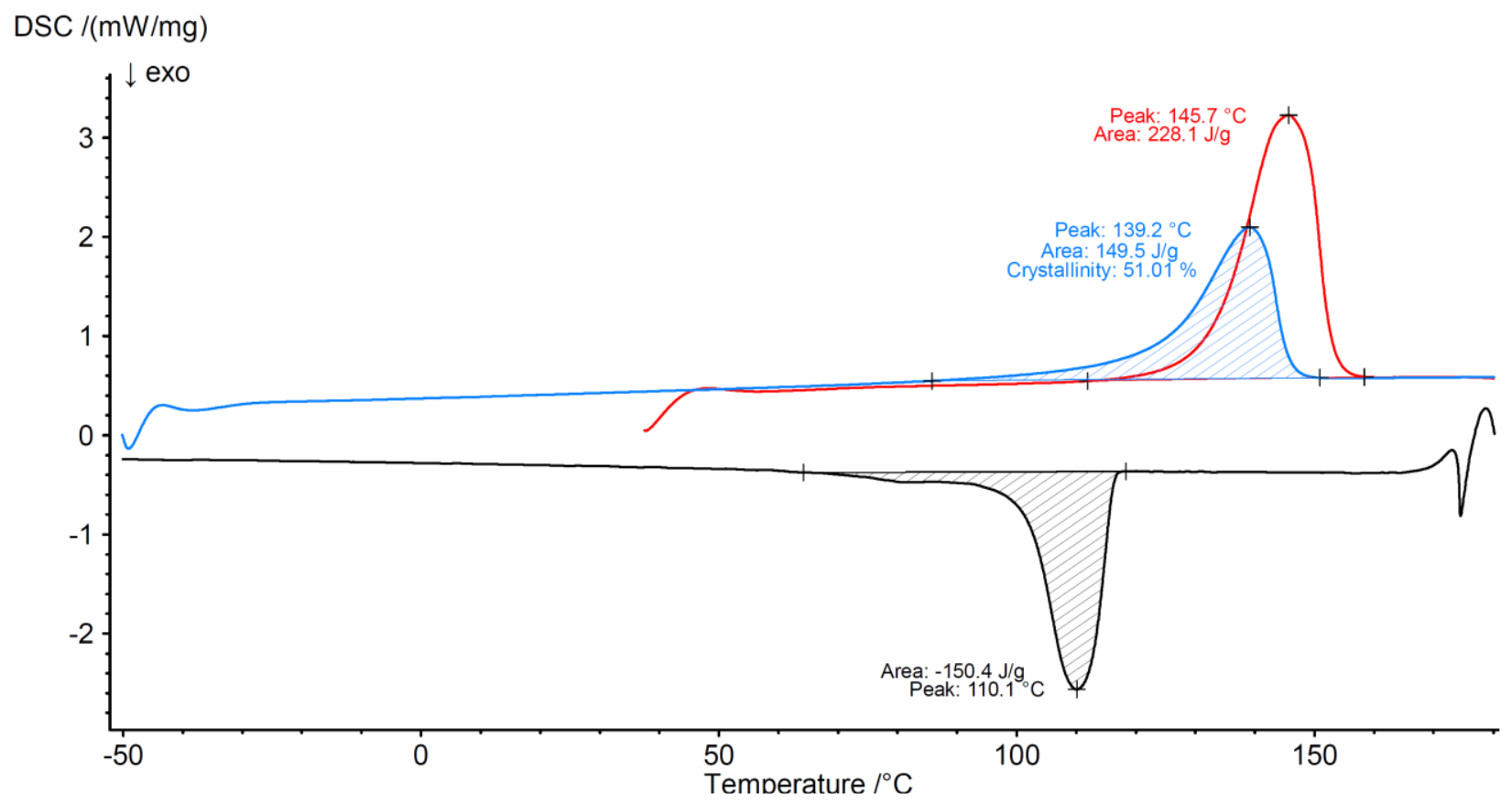

$\mathrm{DSC} /(\mathrm{mW} / \mathrm{mg})$

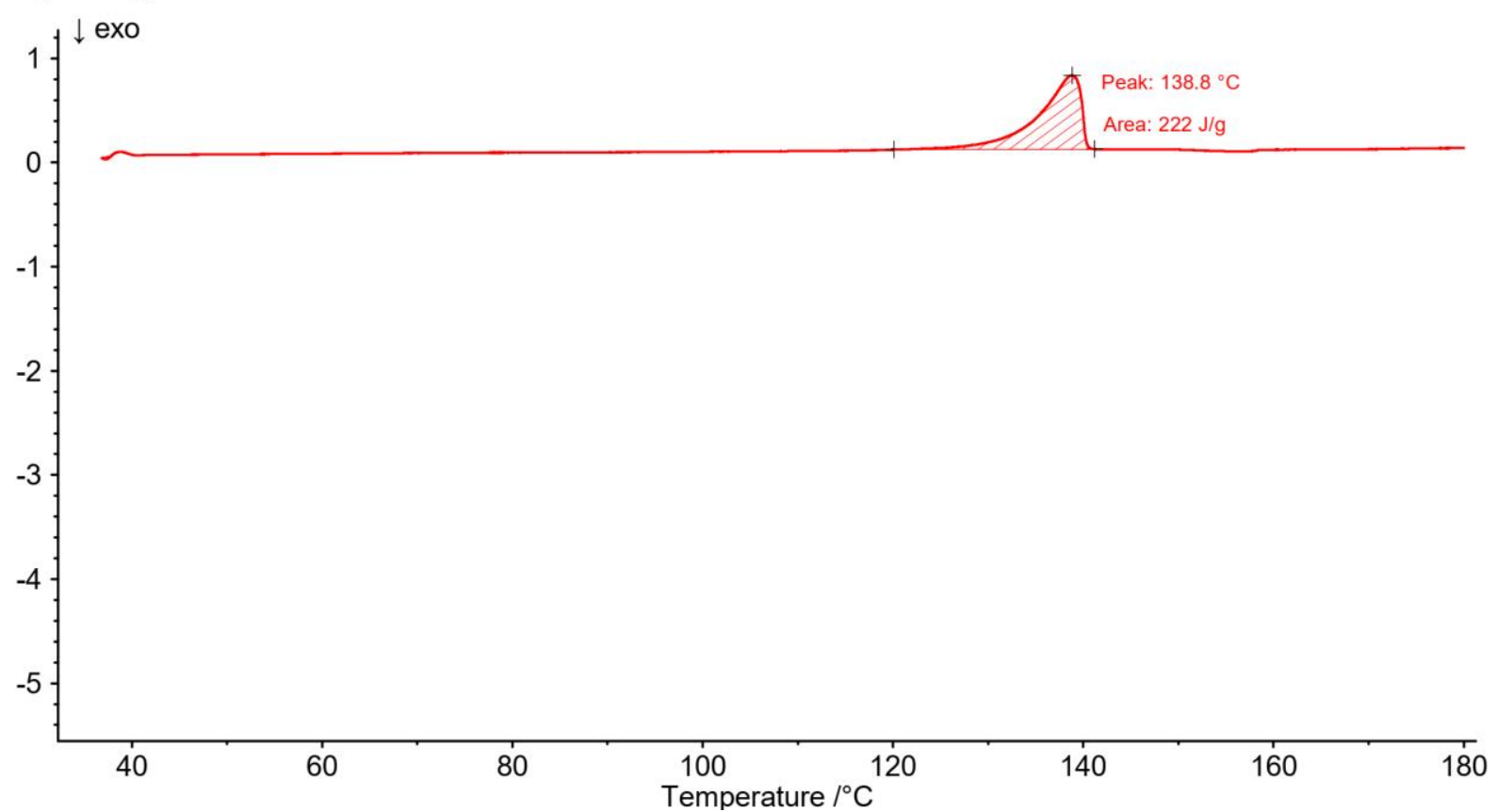

Figure S12. DSC trace of polyethylene obtained (Table 1, entry 9). Top: measured with $10 \mathrm{~K}$ $\min ^{-1}$ heating rate (red curve: $1^{\text {st }}$ heating; black curve: $1^{\text {st }}$ cooling; blue curve: $2^{\text {nd }}$ heating). Bottom: measured with $1 \mathrm{~K} \mathrm{~min}^{-1}$ (only $1^{\text {st }}$ heating shown). 


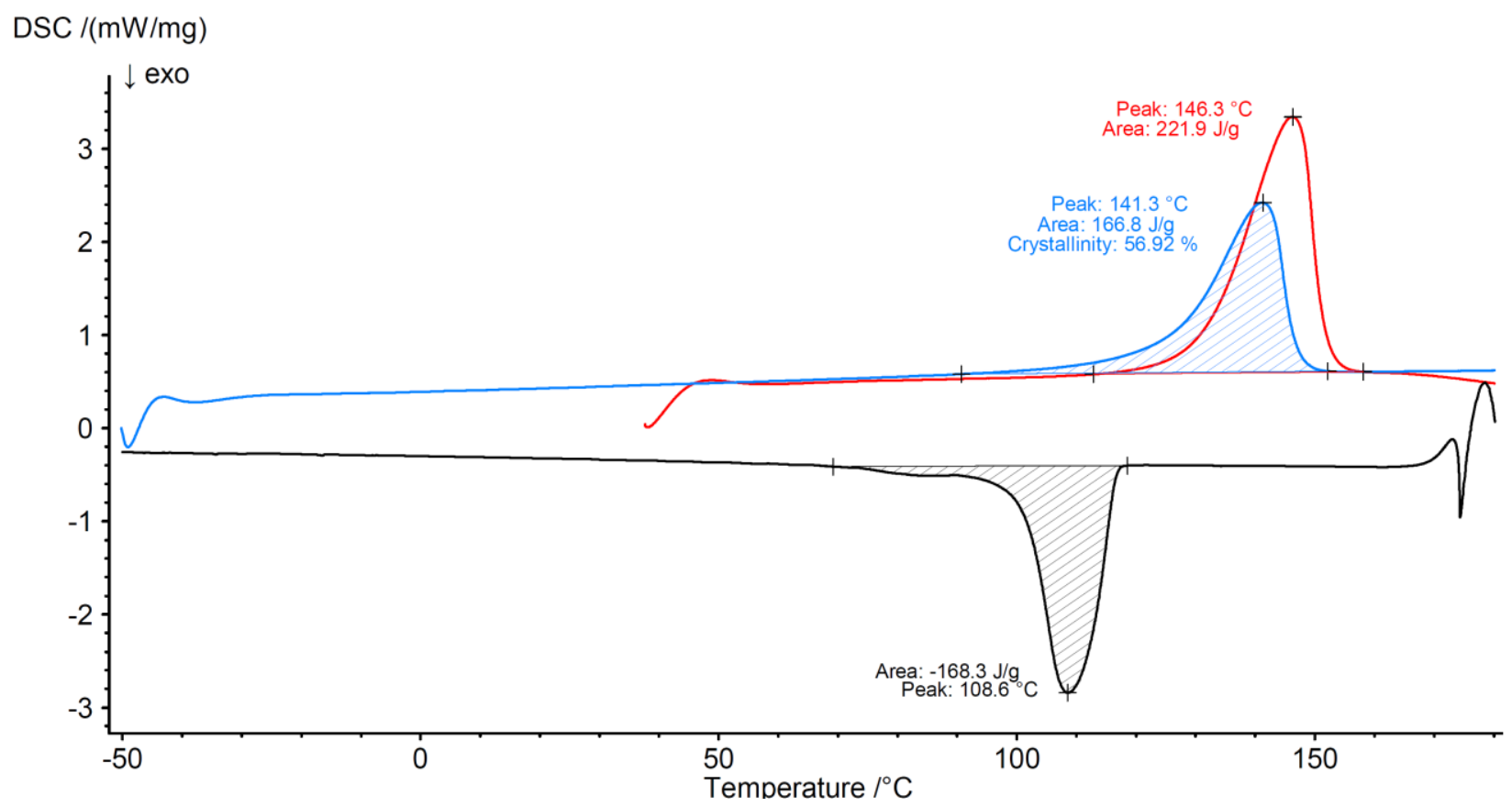

Figure S13. DSC traces of polyethylene obtained (Table 1, entry 10), measured with $10 \mathrm{~K} \mathrm{~min}^{-1}$ heating rate (red curve: $1^{\text {st }}$ heating; black curve: $1^{\text {st }}$ cooling; blue curve: $2^{\text {nd }}$ heating).

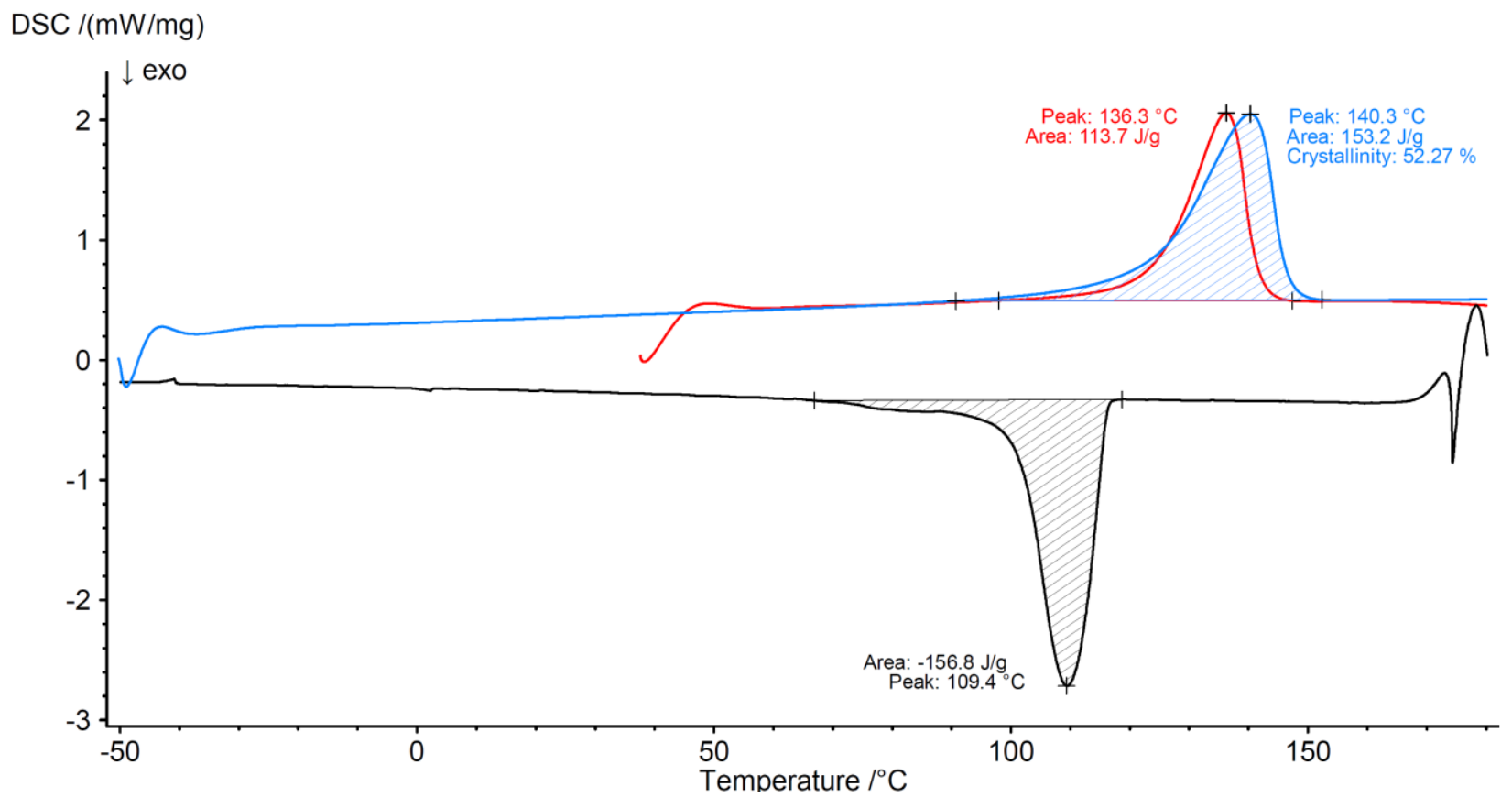

Figure S14. DSC traces of polyethylene obtained (Table 1, entry 11), measured with $10 \mathrm{~K} \mathrm{~min}^{-1}$ heating rate (red curve: $1^{\text {st }}$ heating; black curve: $1^{\text {st }}$ cooling; blue curve: $2^{\text {nd }}$ heating). 
5.4 GPC traces

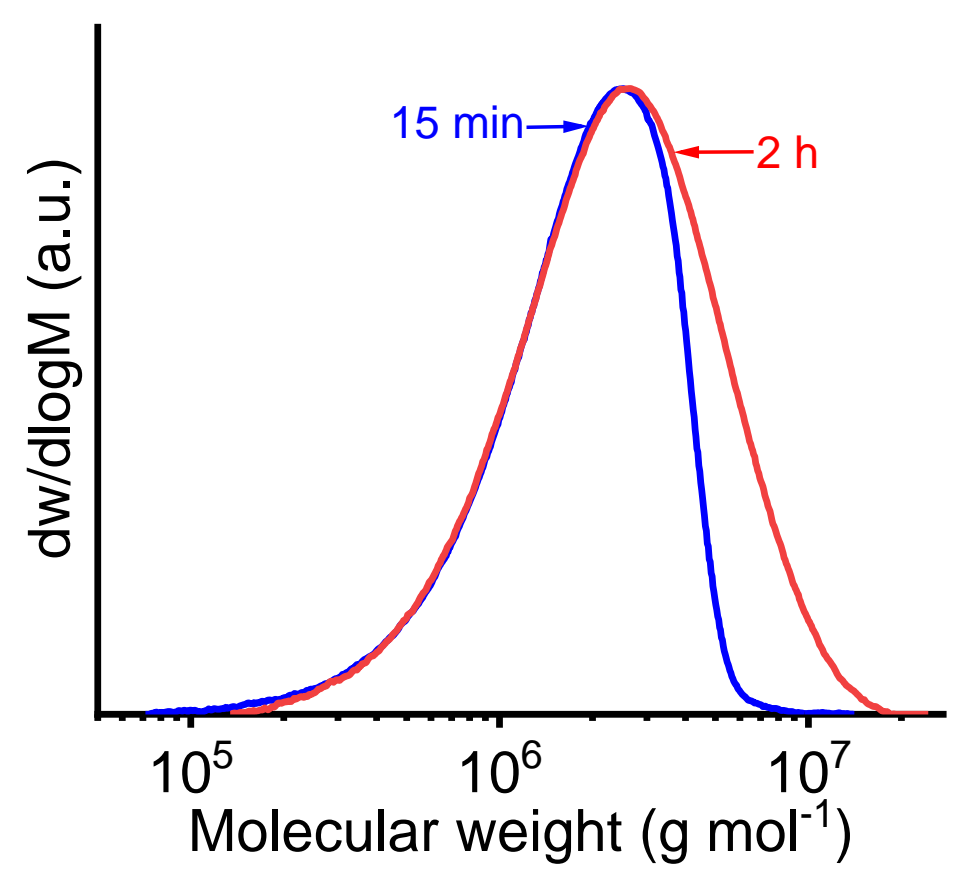

Figure S15. GPC traces of polyethylene obtained with catalyst precursor $1\left(30^{\circ} \mathrm{C}, 40 \mathrm{bar}\right)$.

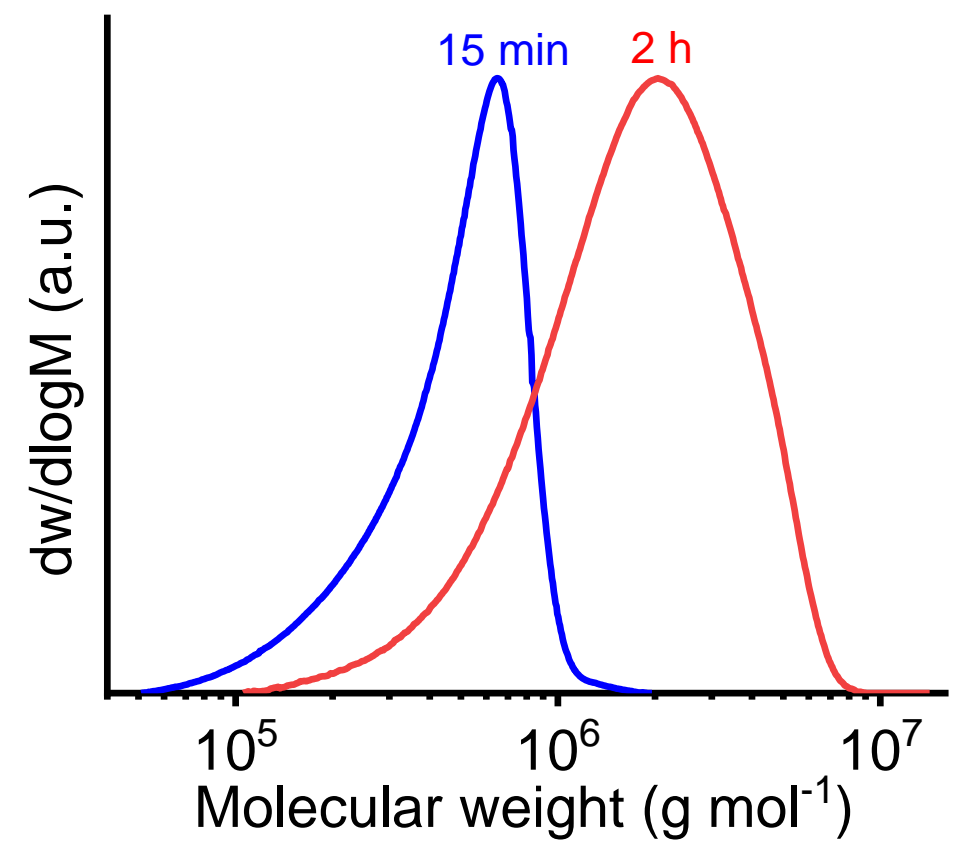

Figure S16. GPC traces of polyethylene obtained with catalyst precursor $2\left(30^{\circ} \mathrm{C}, 40 \mathrm{bar}\right)$. 


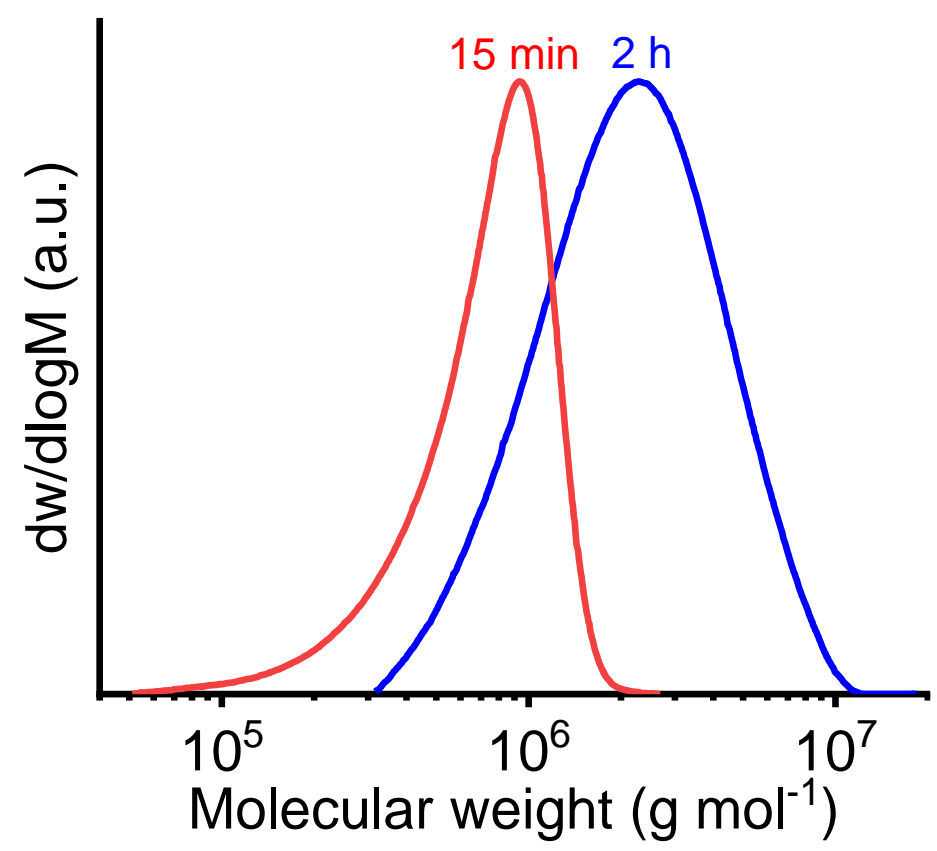

Figure S17. GPC traces of polyethylene obtained with catalyst precursor $4\left(30^{\circ} \mathrm{C}, 40 \mathrm{bar}\right)$.

5.5 Mass flow profiles of aqueous polymerizations

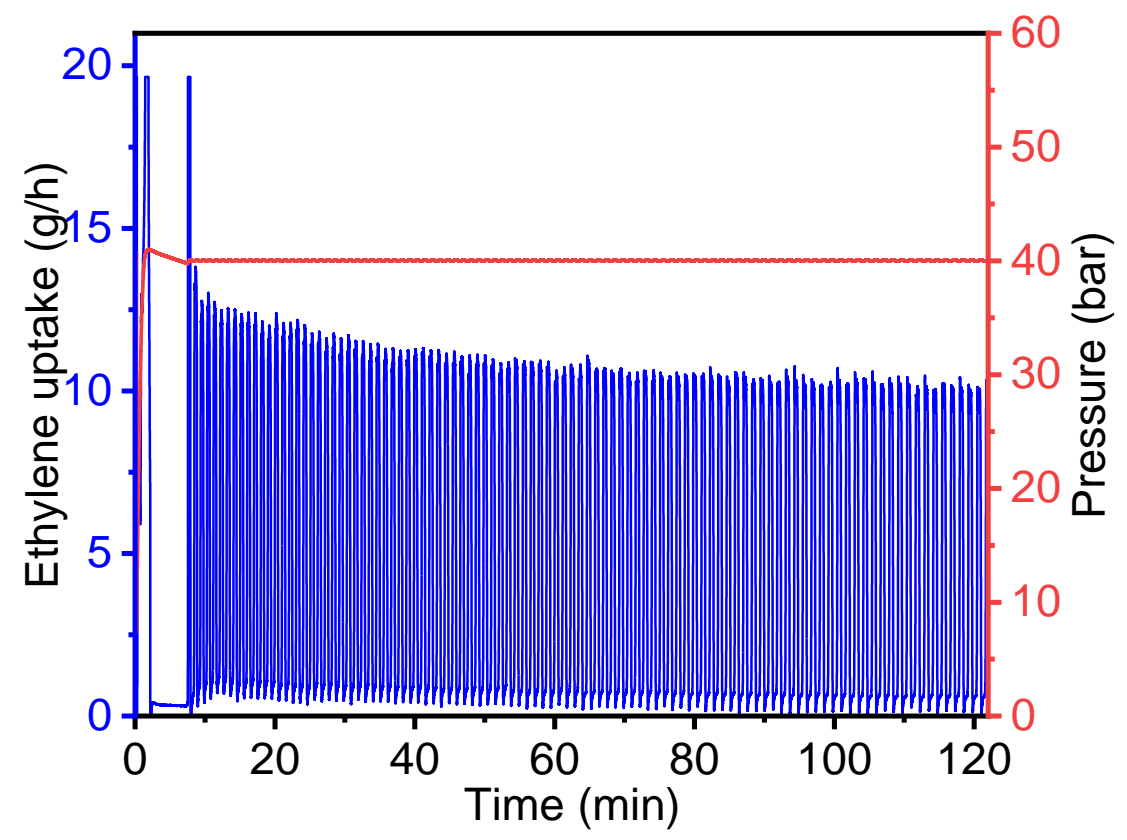

Figure S18. Ethylene uptake of aqueous polymerization with $3\left(30^{\circ} \mathrm{C}, 40\right.$ bar, Table 1, entry 9). 


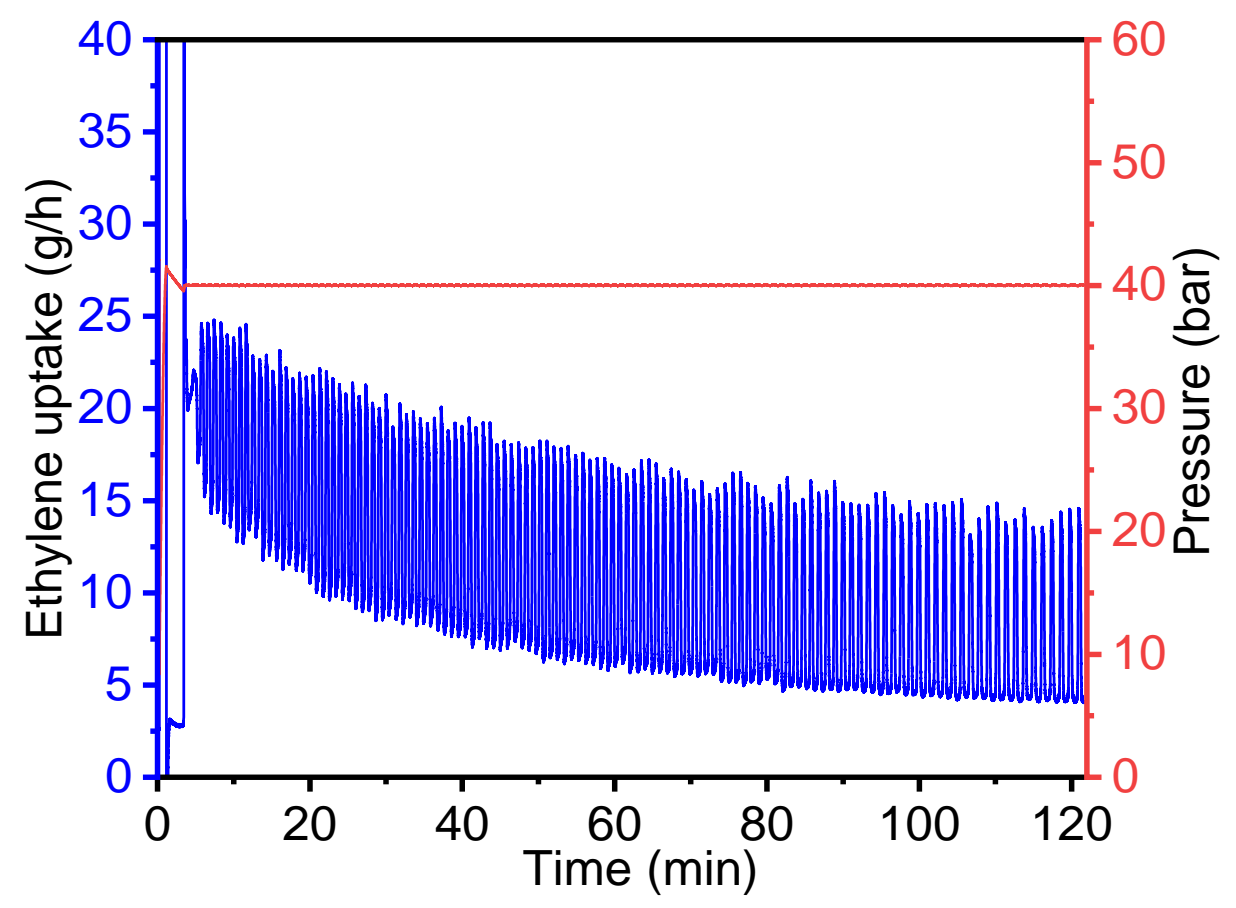

Figure S19. Ethylene uptake of aqueous polymerization with $3\left(50{ }^{\circ} \mathrm{C}\right.$, 40 bar, Table 1 , entry 10).

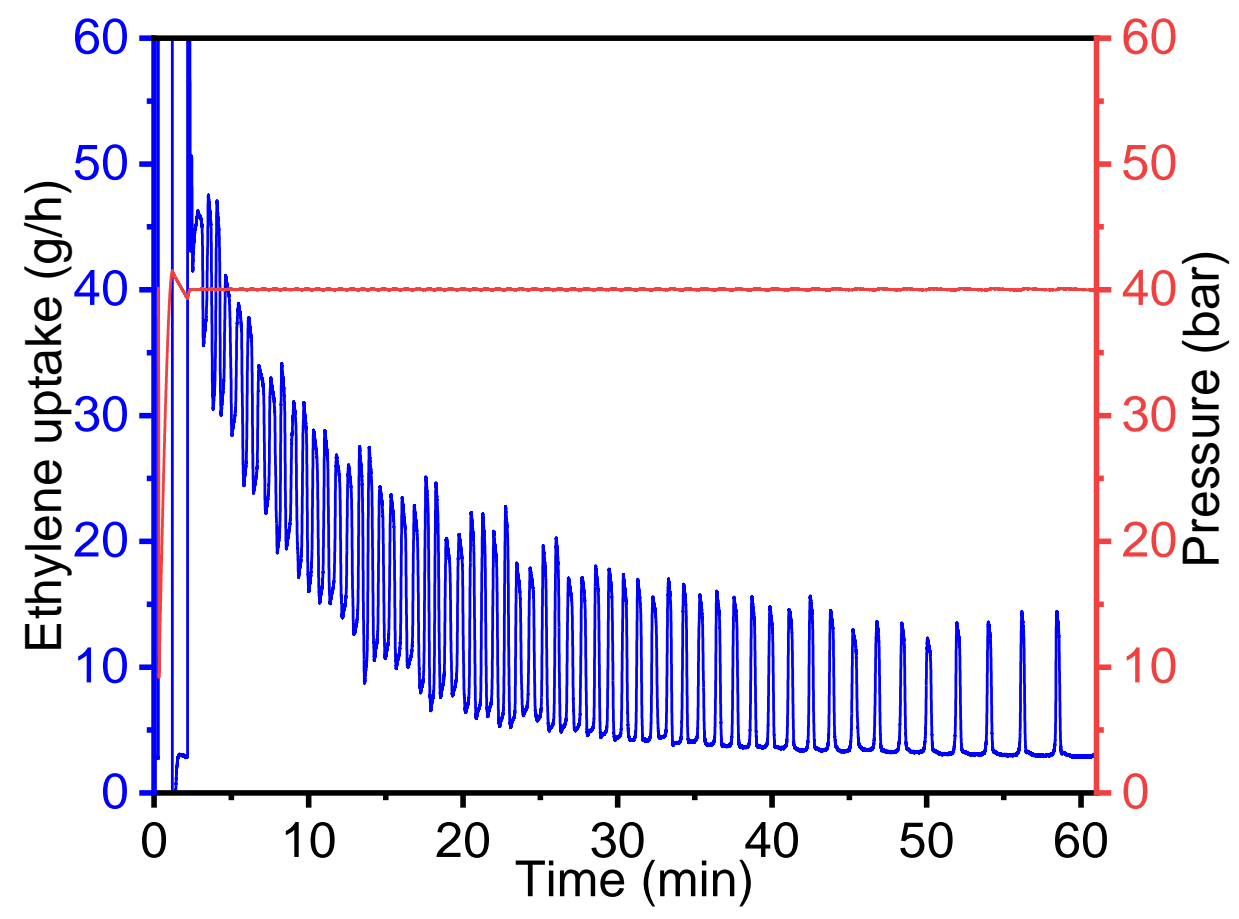

Figure S20. Ethylene uptake of aqueous polymerization with $3\left(70{ }^{\circ} \mathrm{C}, 40\right.$ bar, Table 1 , entry 11$)$. 


\section{Particle analysis of polyethylene nanoparticle dispersions}

\subsection{Particle size statistics}

TEM images reveal a disk-like particle shape. Various orientations of particles are observed in the TEM samples, such that the thickness $(H)$ and the diameter $(D)$ of particles can be determined from particles standing upright $(H, D)$ or laying flat i.e. perpendicular to the electron beam $(D)$ on the substrate (Tables $\mathrm{S} 2$ and $\mathrm{S} 3$. Errors given are standard deviations).

Table S2. Thickness of particles determined via TEM measurements

\begin{tabular}{cccc}
\hline Entry in Table 1 & $\mathrm{t}[\mathrm{min}]$ & Number of particles & $H[\mathrm{~nm}]$ \\
\hline 6 & 15 & 12 & $8.0 \pm 0.1$ \\
7 & 30 & 12 & $8.1 \pm 0.1$ \\
8 & 60 & 10 & $8.1 \pm 0.1$ \\
9 & 120 & 10 & $8.0 \pm 0.1$ \\
\hline
\end{tabular}

The thickness is independent of the duration of the polymerization experiment and amounts to about $8 \mathrm{~nm}$ (polymerization temperature $30^{\circ} \mathrm{C}$ ), which agrees with a single lamella.

The average volume of a particle $V_{\text {part }}$ was calculated according to Supplementary Equation S1.

$$
V_{\text {part }}=\frac{1}{4} \pi D^{2} H
$$

The average mass of one particle $m_{\mathrm{part}}$ was determined assuming a polyethylene density of $\rho_{\mathrm{PE}}=$ $0.94 \mathrm{~g} \mathrm{~cm}^{-1}$ (Supplementary Equation S2). The mass of a polymer chain $m_{\text {chain }}$ was calculated from the mass-average molecular weight $M_{\mathrm{w}}$ determined by GPC (Supplementary Equation S3). Together with the mass of a particle this provides the chains per particle ratio $N_{\text {chain }} / N_{\text {part }}$ (Supplementary Equation S4). The particle number $N_{\text {part }}$ was calculated based on the yield of polyethylene $m_{\mathrm{PE}}$ (Supplementary Equation S5). The quality of the data allows for an order of magnitude estimation of the chains per particle and the particle numbers (Table S3). 


$$
\begin{gathered}
m_{\text {part }}=V_{\text {part }} \rho_{P E} \quad \text { (S2) } \\
m_{\text {chain }}=\frac{M_{W}}{N_{A}} \text { with } N_{A}=6.02 \times 10^{23} \mathrm{~mol}^{-1} \\
\frac{N_{\text {chain }}}{N_{\text {part }}}=\frac{m_{\text {part }}}{m_{\text {chain }}}=\frac{V_{\text {part }}{ }^{\circ} \rho_{P E} \cdot N_{A}}{M_{W}} \\
N_{\text {part }}=\frac{m_{P E}}{m_{\text {part }}}=\frac{m_{P E}}{V_{\text {part }}{ }^{*} \rho_{P E}}
\end{gathered}
$$

Table S3. Particle statistics from TEM

\begin{tabular}{cccccccccc}
\hline Entry & Precat. & $\begin{array}{c}\mathrm{t} \\
{[\mathrm{min}]}\end{array}$ & $\begin{array}{c}\text { Yield } \\
{[\mathrm{g}]}\end{array}$ & $\begin{array}{c}\text { number of } \\
\text { particles } \\
\text { analyzed }\end{array}$ & $D[\mathrm{~nm}]$ & $\begin{array}{c}\mathrm{V}_{\text {part }} \\
{\left[\times 10^{3} \mathrm{~nm}^{3}\right]}\end{array}$ & $\begin{array}{c}M_{\mathrm{w}} \\
{\left[\times 10^{6}\right]}\end{array}$ & $\begin{array}{c}\text { Chains } \\
\text { per } \\
\text { particle }\end{array}$ & $\begin{array}{c}N_{\text {part }} \\
{[\mu \mathrm{mol}]}\end{array}$ \\
\hline 1 & $\mathbf{1}$ & 15 & 4.52 & 215 & $22.1 \pm 0.4$ & 3.07 & 2.13 & 0.8 & 2.6 \\
2 & $\mathbf{1}$ & 120 & 23.85 & 268 & $30.1 \pm 0.4$ & 5.69 & 3.00 & 1.1 & 7.4 \\
3 & $\mathbf{2}$ & 15 & 1.58 & 266 & $20.1 \pm 0.3$ & 2.54 & 5.20 & 2.8 & 1.1 \\
4 & $\mathbf{2}$ & 120 & 11.47 & 196 & $27.2 \pm 0.3$ & 4.65 & 2.14 & 1.2 & 4.4 \\
5 & $\mathbf{3}$ & 5 & 0.72 & 168 & $7.4 \pm 0.1$ & 0.344 & 0.16 & 1.2 & 3.7 \\
6 & $\mathbf{3}$ & 15 & 2.03 & 201 & $12.6 \pm 0.2$ & 1.00 & 0.43 & 1.3 & 3.6 \\
7 & $\mathbf{3}$ & 30 & 3.73 & 248 & $15.3 \pm 0.2$ & 1.47 & 0.76 & 1.1 & 4.5 \\
8 & $\mathbf{3}$ & 60 & 8.10 & 207 & $21.4 \pm 0.4$ & 2.88 & 1.57 & 1.0 & 4.8 \\
9 & $\mathbf{3}$ & 120 & 9.35 & 211 & $27.1 \pm 0.5$ & 4.61 & 2.62 & 1.0 & 3.6 \\
12 & $\mathbf{4}$ & 15 & 2.07 & 212 & $11.7 \pm 0.2$ & 0.86 & 0.78 & 0.6 & 4.3 \\
13 & $\mathbf{4}$ & 120 & 13.50 & 188 & $31.3 \pm 0.5$ & 6.16 & 2.58 & 1.3 & 3.9 \\
\hline
\end{tabular}

Entries correspond to entries in Table 1. For conditions, cf. Table 1. 
6.2 TEM images of polyethylene nanoparticles
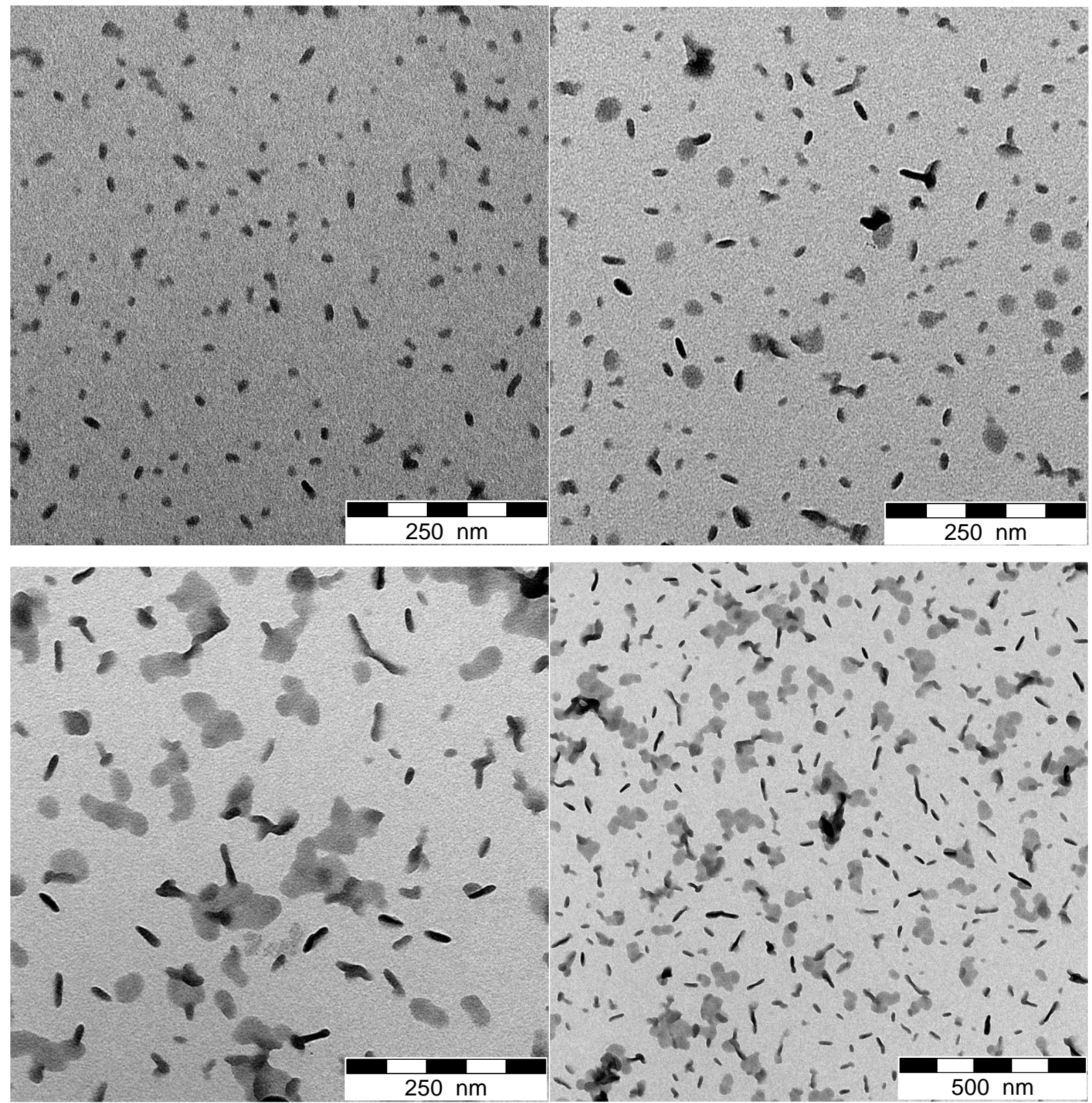

Figure S21. TEM image of polyethylene dispersions obtained after 5 min polymerization time (top left; entry 5, Table 1), 30 min (top right, entry 7, Table 1) and 120 min (bottom, entry 9, Table 1). 


\section{References}

(1) Göttker-Schnetmann, I.; Mecking, S. A Practical Synthesis of $\left[(\right.$ tmeda $\left.) \mathrm{Ni}\left(\mathrm{CH}_{3}\right)_{2}\right]$, Isotopically Labeled [(tmeda) $\left.\mathrm{Ni}\left({ }^{13} \mathrm{CH}_{3}\right)_{2}\right]$, and Neutral Chelated-Nickel Methyl Complexes. Organometallics 2020, 39, 3433-3440.

(2) Jones, D. J.; Gibson, V. C.; Green, S. M.; Maddox, P. J.; White, A. J. P.; Williams, D. J. Discovery and Optimization of New Chromium Catalysts for Ethylene Oligomerization and Polymerization Aided by High-Throughput Screening. J. Am. Chem. Soc. 2005, 127, 11037-11046.

(3) Kondoh, A.; Aoki, T.; Terada, M. Synthesis of Phenanthrene Derivatives by Intramolecular Cyclization Utilizing the [1,2]-Phospha-Brook Rearrangement Catalyzed by a Brønsted Base. Chem. Eur. J. 2015, 21, 12577-12580.

(4) Schnitte, M.; Staiger, A.; Casper, L. A.; Mecking, S. Uniform shape monodisperse single chain nanocrystals by living aqueous catalytic polymerization. Nat. Commun. 2019, 10, 2592.

(5) Zhang, Y.; Mu, H.; Pan, L.; Wang, X.; Li, Y. Robust Bulky [P,O] Neutral Nickel Catalysts for Copolymerization of Ethylene with Polar Vinyl Monomers. ACS Catal. 2018, 8, 59635976.

(6) Zhang, Y.; Mu, H.; Wang, X.; Li Pan; Li, Y. Elaborate Tuning in Ligand Makes a Big Difference in Catalytic Performance: Bulky Nickel Catalysts for (Co)polymerization of Ethylene with Promising Vinyl Polar Monomers. ChemCatChem 2019, 11, 2329-2340.

(7) Baur, M.; Lin, F.; Morgen, T. O.; Odenwald, L.; Mecking, S. Polyethylene Materials with In-Chain Ketones from Non-Alternating Catalytic Copolymerization. Science 2021, 374, 604-607.

(8) X-RED version 1.31 (2005) Stoe Data Reduction Program.

(9) Dolomanov, O. V.; Bourhis, L. J.; Gildea, R. J.; Howard, J. A. K.; Puschmann, H. OLEX2: a complete structure solution, refinement and analysis program. J. Appl. Crystallogr. 2009, 42, 339-341.

(10) Sheldrick, G. M. SHELXT - Integrated space-group and crystal-structure determination. Acta Cryst. A 2015, 71, 3-8.

(11) Bourhis, L. J.; Dolomanov, O. V.; Gildea, R. J.; Howard, J. A. K.; Puschmann, H. The anatomy of a comprehensive constrained, restrained refinement program for the modern computing environment - Olex2 dissected. Acta Cryst. A 2015, 71, 59-75.

(12) Spek, A. L. Single-crystal structure validation with the program PLATON. J. Appl. Crystallogr. 2003, 36, 7-13. 